\title{
HASTE BLOQUEADA \\ "FACULDADE DE MEDICINA DE RIBEIRÃO PRETO" experiência clínica no tratamento das fraturas femorais
}

\author{
RIBEIRÃO PRETO SCHOOL OF MEDICINE LOCKING NAIL: \\ Clinical Experience in the Femoral Fractures Treatment
}

\author{
Fernado Mendes Paschoal ${ }^{1}$; Cleber Antonio Jansen Paccola ${ }^{2}$
}

\section{RESUMO}

Uma série de 103 casos de fraturas diafisárias complexas do fêmur foram tratadas com a haste intramedular bloqueada FMRP, no período de maio de 1987 a dezembro 1995. Das 103 fraturas, 67 eram cominutivas, 12 bifocais (segmentar), 4 espirais, 13 proximais e 21 distais, instáveis, rotacionalmente, da diáfise femoral. Do total dos casos, constatou-se 97 bloqueios estáticos e 6 dinâmicos. Dessas 97 estáticas, 7 foram dinamizadas durante a evolução. Clínica e radiográficamente a consolidação ocorreu em 97,09\% dos casos, com média de 16,72 semanas e em 3 casos não houve consolidação. Houve 4 casos de infecção suspeita e 3 estabelecidas que foram debeladas e evoluíram para consolidação. Houve 81 casos de encurtamentos que variaram entre 0,5 a 4 cm com média de $1 \mathrm{~cm}$. O encurtamento menor ou igual a $2 \mathrm{~cm}$ ocorreu em 73 casos. Desvio de alinhamento em qualquer plano acima de $10^{\circ} \mathrm{e}$ igual a $15^{\circ}$ foi observado em 8 pacientes. Houve 10 casos de deformidades rotacionais, porém nenhum caso acima de $10^{\circ}$. A incidência de infecção foi baixa e a de consolidação alta. A estabilização dessas fraturas complexas permitiu imediata mobilização do paciente, reabilitação precoce do membro e diminuição da permanência hospitalar, excetuando os politraumatizados. A haste FMRP permitiu o tratamento dessas fraturas sem o uso de intensificador de imagens e de fresas flexíveis com baixo custo operacional. Os resultados foram semelhantes aos obtidos com as hastes intramedulares bloqueadas que necessitam de aparelhagem técnica mais sofisticada, porém com vantagens para o paciente e a equipe cirúrgica.

\section{SUMMARY}

A series of 103 cases of complex femoral fracture were treated with FMRP (Faculdade de Medicina de Ribeirão Preto) nail. These fractures were treated from May 1987 until December 1995. From the 103 fractures, 67 were cominutive, 12 bifocal (segmental), 4 spiral, 13 proximal e 21 distal and unstable rotationaly. From the total of cases, 97 were statically locked and 6 dynamic. From these 97, only 7 were dynamised during evolution. Clinical and radiographic union had occurred in 97.09 per cent of cases with average of 16.72 weeks. In 3 cases the union did not occur with interlocking nail. There were 4 cases with suspected and 3 with established infection that were healed by the time of evolution. There were 81 cases of shortening that varied from 0.5 centimeter to 4 centimeters with an average of 1.0 centimeter. The shortening of less than and equal 2 centimeters occurred in 73 cases. The alignment distortion in any plane up from 10 degrees and equal to 15 degrees was observed in 8 patients. There were 10 cases of rotational deformities, but no case above 10 degrees. The infection incidence was low; and, the union incidence was high. The fracture stabilization had immediately allowed patient's mobilization, early rehabilitation and decreasing hospital stay, except in politrauma cases. The FMRP nail had allowed treating these kind of fractures without using any image intensifier or flexible reamers. Hence this method had turned the cost of treatment down. The outcomes were matching to those reported with intramedullary interlocking nailing which needs technical equipment more sophisticated.

${ }^{1}$ Pós-Graduando do Dept ${ }^{\circ}$ de Cirurgia, Ortopedia e Traumatologia, Faculdade de Medicina de Ribeirão Preto-USP

${ }^{2}$ Professor Titular do Dept $^{\circ}$ de Cirurgia, Ortopedia e Traumatologia, Faculdade de Medicina de Ribeirão Preto-USP 


\section{INTRODUÇÃO}

As fraturas cominutivas da diáfise femoral estão entre as mais comuns na clínica ortopédica. São lesões geralmente graves e muitas vezes associadas a comprometimento de outros órgãos e que podem determinar deformidades e seqüelas ao paciente, em função de complicações imediatas ou tardias.

Nas últimas décadas, vêm sendo desenvolvidos diferentes processos de travamento de haste intramedular, combinada a foco fechado e com a inserção de parafusos que travam o osso à haste. Por este método, o bloqueio estático controla a rotação e a telescopagem, possibilitando a conversão para bloqueio dinâmico, quando necessário.

Além disso, a haste intramedular bloqueada, se observada a indicação correta e se realizada com técnica apropriada, pode ser aplicada em outras fraturas, cujo tipo e localização não permitem a execução de uma haste convencional.

Portanto, em função dos excelentes resultados clínicos, apresentados na literatura, ${ }^{(15,16,30,33,34)}$ com o uso de haste bloqueada e devido a seu elevado custo e necessidade de infra-estrutura hospitalar sofisticada para a sua execução, considerou-se importante o desenvolvimento de novas técnicas que minimizem custos e equipamentos especiais. Dessa maneira, procurou-se desenvolver uma haste bloqueada, a partir de estudos iniciados na Faculdade de Medicina de Ribeirão Preto da Universidade de São Paulo, em 1987. Nesses estudos foram apresentados alguns resultados clínicos na dissertação de mestrado(27), após um período de aplicação, quando 103 cirurgias foram realizadas, e foram analisados os resultados clínicos encontrados, é apresentanda, aqui, a experiência clínica como conclusão da pesquisa.

O material apresentado é a maior casuística de fraturas do fêmur operadas com a haste FMRP (Faculdade de Medicina de Ribeirão Preto) e é também relevante, porque as cirurgias foram realizadas em um hospital universitário, onde foi desenvolvida a haste FMRP. As osteossínteses foram feitas pelos autores, por ortopedistas da instituição e por médicos residentes.

A técnica e o instrumental desenvolvidos apresentam as seguintes característica: a) baixo custo; b) dispensam a utilização do intensificador de imagem, de mesa especial (ortopédica); e de fresas flexíveis.

O objetivo da pesquisa foi avaliar clinicamente os resultados do tratamento de 103 fraturas femorais instáveis com o uso do método de haste intramedular bloqueada FMRP desenvolvida em Ribeirão Preto e demonstrar a eficácia do método bem como as vantagens da haste utilizada.

\section{CASUÍSTICA E MÉTODOS Casuística}

Nesse item serão apresentados os pacientes operados com a haste intramedular FMRP, os implantes e o instrumental utilizado na experiência.

\section{INTRODUCTION}

Comminutive fractures of the femoral diaphysis are one of the commonest in the orthopedic clinic. They are generally severe lesions frequently associated to deteriorarion of other organs and they can originate deformities and sequelae in the patients, as a function of immediate or late complications.

In the last decades, different intramedullary locking nail processes have been developed, combined to closed focus and with the insertion of screws that lock the bone to the nail. Using this method, static locking controls rotation and telescoping, possibilitating conversion for dynamic lock, when necessary.

Besides that, the intramedullary locking nailing, when adequately indicated and carried out with the appropriate technique, can be applied to other fractures, where type and localization hinder the use of the conventional nails.

Thus, according to the excellent clinical results presented in the literature ${ }^{(15,16,30,33,34)}$ using the locking nail and due to high cost and the need of a sophisticated hospital infra-structure, the development of new techniques which minimize costs and special equipments was considered important. A locking nail was developed from studies carried out in 1987 in the Ribeirão Preto College of Medicine, University of São Paulo. These studies included the clinical results from a master degree dissertation (27), a period in which 103 surgeries were effected, and the clinical results were analyzed. This paper presents the clinical experience as the conclusion of the investigation.

The material presented is the casuistic of femoral fractures operated on with the FMRP (Ribeirão Preto College of Medicine) locking nail and it is also relevant since the operations were carried out in the university hospital where the FMRP locking nail was developed. The osteosyntheses were carried out by the author, by orthopedists of the institution and by residents.

The technique and the instruments developed present the following characteristics: a) low cost; b) dispense the utilization of the image intensifier, special (orthopedic) table, and flexible reamers.

The aim of the study was to clinically evaluate the results of the treatment of 103 unstable femoral fractures using the FMRP intramedullary locking nail developed in Ribeirão Preto and to demonstrate the method efficiency as well as the advantages of the nail.

\section{CASUISTIC AND METHODS Casuistic}

The patients operated on with the FMRP intramedullary nail, the inplants and the instruments used in the investigation are presented.

From May, 1987 to December, 1995, 111 pacientes were operated on with the FMRP intramedullary locking nail, in the "Hospital das Clínicas", Ribeirão Preto College of Medicine, University of São Paulo, and 11 in the UNICAMP "Hospital das Clínicas" (these data were discarded since the patients could not be found), summing up 122 
No período entre maio de 1987 a dezembro de 1995, 111 pacientes foram operados com a haste intramedular bloqueada FMRP, no Hospital das Clínicas da Faculdade de Medicina de Ribeirão Preto da Universidade de São Paulo, e 11 no Hospital das Clínicas da UNICAMP (dados desprezados por falta de acesso aos pacientes), totalizando 122 pacientes com 124 fraturas diafisárias femorais. Entretanto, dos 111 pacientes operados no Hospital das Clínicas de Ribeirão Preto da Universidade de São Paulo, 10 deixaram de ser incluídos neste trabalho por falta de comparecimento à reavaliação.

Este trabalho apresenta os dados de 103 fraturas (101 pacientes) tratadas com haste intramedular bloqueada FMRP. Das 103 fraturas (101 pacientes), 57 foram à direita e 46 à esquerda, incluindo 2 casos bilaterais. Destes pacientes, 77 eram do sexo masculino e 24 do sexo feminino. Quanto às características das fraturas, foram observadas 88 fechadas e 15 fraturas expostas. Das fraturas expostas, segundo a classificação de Gustilo et al..(13) 6 (5,50\%) pertenciam ao grau I; 9 (8,26\%) ao grau II. O grau de cominuição das fraturas foi avaliado segundo os critérios da classificação $A O$, sendo observado mais freqüentemente fraturas do tipo B e C. A grande maioria foi pacientes politraumatizados com outras fraturas associadas. Todos foram operados sendo utilizado no tratamento haste intramedular bloqueada FMRP de parede de 1,2 $\mathrm{mm}$ e haste de parede de 2,0 $\mathrm{mm}$ de espessura ${ }^{\left({ }^{34)} \text {. }\right.}$

A idade dos pacientes variou entre 14 e 84 anos de idade, sendo a média em torno de 30,47 anos.

Para classificar as 103 fraturas femorais, foi utilizada a classificação do grupo AO/ASIF ${ }^{1}$ diagrama do fêmur, conforme se observa na Figura 1, segundo Müller(23).

Registrou-se 13 fraturas do tipo A (12,62\%), 61 do tipo B (59,22\%), 29 do tipo C (28,16\%) e a indicação

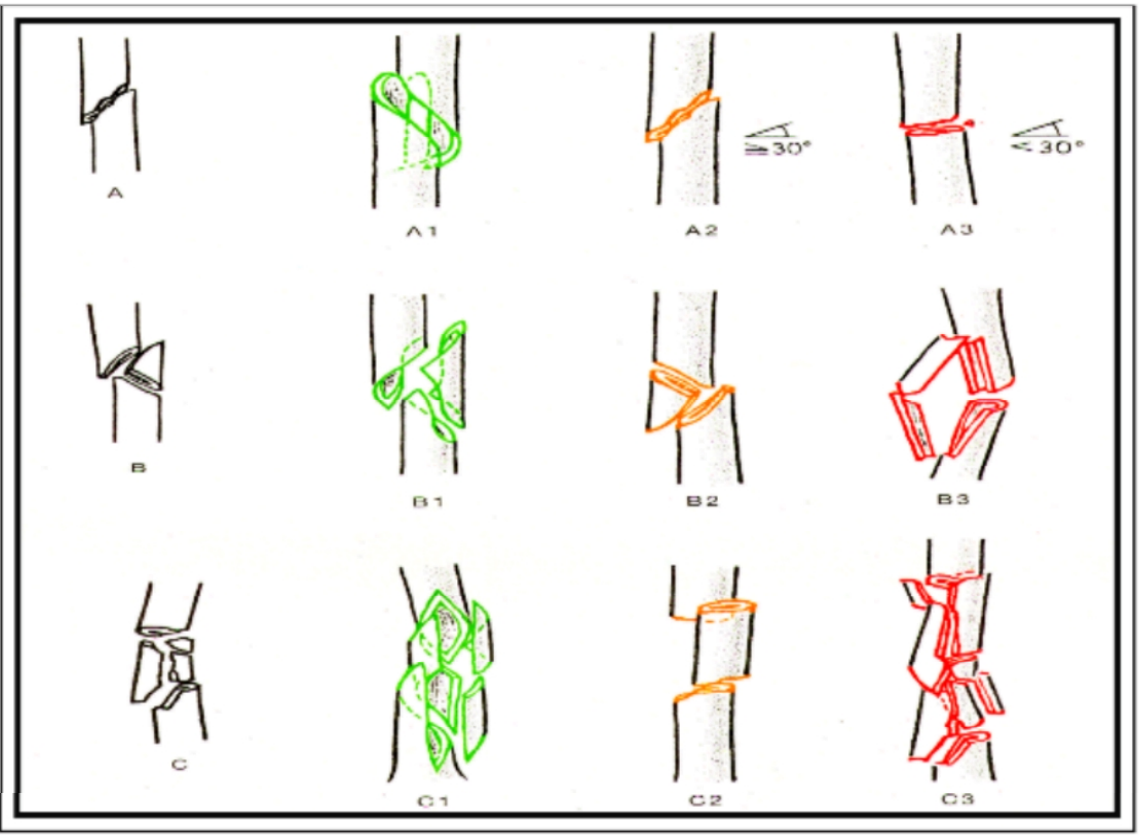

Figura 1 - Classificação das fraturas diafisárias do fêmur de acordo com classificação da $A O^{(23)}$

patients with 124 diaphyseal femoral fractures. However, among the 111 patientes operated on in the Ribeirão Preto "Hospital das Clínicas", 10 were not included in this study since they did not show up for reevaluation.

This study presents data from 103 fractures (101 patients) treated with the FMRP intramedullary locking nail. Among the 103 fractures (101 patients), 57 were right and 46 left, including 2 bilateral cases. Among these patients, 77 were male and 24 female. Concerning the fracture characteristics, 88 were closed and 15 open. Among the open fractures, according to Gustilo's et al. ${ }^{(13)}$ classification, 6 (5.50\%) were grade I; 9 (8.26\%) were grade II. The fractures comminution was evaluated according to the $A O$ classification criteria, and types $B$ and $C$ were more frequently observed. Most of the patients presented polytraumas with other associated fractures. All of them were operated on using FMRP intramedullary $1.22 \mathrm{~mm}$ and $2.0 \mathrm{~mm}$ wall thick nails (34).

The ages of the patients ranged from 14 to 84 years, 30.47 years on average.

To classify the 103 fractures, a AO/ASF' group classification femur diagram was used, as Figure 1 presents according to Müller ${ }^{(23)}$.

Figure 1 - Classification of diaphyseal femoral fractures according to the $A O$ classification ${ }^{(23)}$.

Thirteen fractures type $A(12.62 \%), 61$ type $B(59.22 \%), 29$ type C (28.16\%) were registered and the FMRP locking nail indication was due to comminution of the fractures, in 67 da haste bloqueada FMRP foi devido à cominuição da fratura, em 67 pacientes (57,26\%); em 21 (17,95\%), porque a fratura na diáfise era abaixo do ístmo (distal); em 13 (11,11\%), porque era acima do ístmo (proximal); em 12 (10,26\%) por ser segmentar; e 4 (3,42\%) por serem espirais ou oblíquas longas.

A distribuição das fraturas quanto à localização foi: 28 proximais $(P), 5$ proximal e média $(P / M), 37$ média $(M), 3$ média e distal $(M / D)$ e 30 distal (D). patients (57.26\%) because they were above the isthmus (proximal), in 12 (10.26\%) because they were segmentar, and in 4 (3.42\%) because they were spiral or long oblique.

Distribution of the fractures concerning localization was: 28 proximal $(P), 5$ proximal and median (P/M), 37 median (M), 3 median and distal (M/D), and 30 (distal).

1 AO/ASIF ( Arbeitsgemeinschaft für Osteosyntesefragen/ Association for the Study of Internal Fixation). 


\section{Características da Haste}

A haste e o instrumental especial foram confeccionados pela Schobell Indústria Ltda (Rio Claro/ São Paulo/Brasil) e utilizados nos pacientes com fraturas femorais complexas. Estes pacientes foram operados com a haste intramedular, cuja característica era a de uma haste convencional de Küntscher com padrão de $12 \mathrm{~mm}$ de diâmetro secção transversal com formato de folha de trevo modificada e confeccionada em aço inoxidável 316 L, com 12 perfurações, sendo dois furos proximais, que se encontram numa inclinação de $60^{\circ}$, e dez distais, que permitem um grau de liberdade dos parafusos de $60^{\circ}$ ao longo da fenda da haste e do seu plano de simetria, permitindo direcionamento através dos furos em sentido convergente ou divergente e, assim, travando a haste no canal medular em sentido latero-lateral, como mostra a Figura 2. A parede da haste tem espessura de 2,0 $\mathrm{mm}$ ao invés de 1,2 $\mathrm{mm}$ como a haste clássica de Küntscher.

Os parafusos são semelhantes aos do tipo AO/ASIF, 4,5 mm, com rosca apenas nos seus $16 \mathrm{~mm}$ finais.

O instrumental foi especialmente desenvolvido, segundo Paschoal(27) para o emprego da implantação da haste bloqueada FMRP.

O bloqueio proximal é realizado inserindo-se dois parafusos com o auxílio de um guia proximal, que é conectado ao extremo cranial da haste.

O travamento distal é realizado conectando-se um guia distal no guia proximal, o qual orienta o local onde deve ser feito um orifício na córtex lateral do fêmur, na altura de um dos furos mais distais da haste, na altura da região metaepifisária. Esse orifício serve de guia para a remoção de um cilindro ósseo de $1,5 \mathrm{~cm}$ de diâmetro da cortical lateral com o auxílio de uma trefina especial. Curetagem adicional, no fundo do defeito criado, permite a localização da haste dentro do canal medular. Observando-se a haste dentro do canal e a posição do guia proximal conectado à haste, faz-se uma perfuração cerca de $5 \mathrm{~cm}$, cranialmente ao defeito, passando por ambas as corticais e por um dos orifícios da haste, onde se coloca um parafuso de tamanho adequado. O cilindro ósseo é então recolocado em seu local original, usando-se parafuso que passa através dele, da haste, e de perfuração na cortical medial, realizando o travamento distal adicional e ocluindo o defeito.

Em 41 pacientes, foi utilizado haste de $1,2 \mathrm{~mm}$ de espessura de parede; em 62 pacientes, haste de $2,0 \mathrm{~mm}$ de espessura de parede.

Figura 2 - Vista geral dos implantes de haste bloqueada do sistema FMRP:

A) porção distal da haste, evidenciando a diferente inclinação em que os parafusos podem ser inseridos; $B$ ) e C)

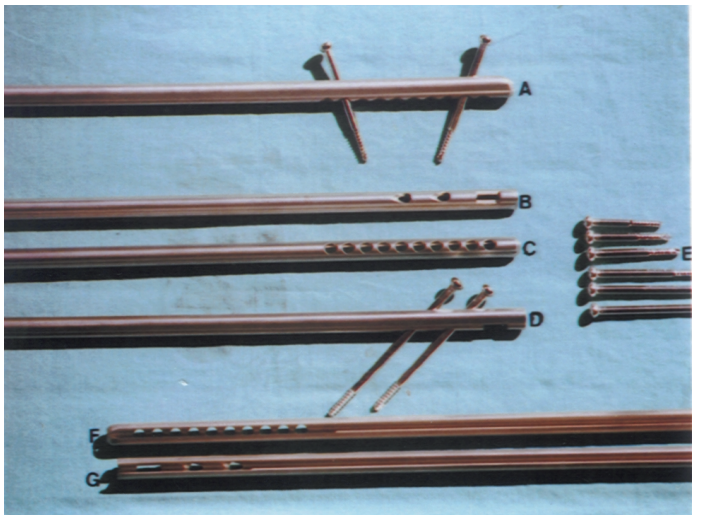
porção proximal e distal da haste, respectivamente, vistas pelas faces que ficam voltadas para a cortical medial do fêmur; D) porção proximal com os dois parafusos nos respectivos furos; E) parafusos de travamento; F) e G) porção distal e proximal, respectivamente, vistas pelas faces que ficam voltadas para a cortical lateral do fêmur.

\section{Characteristics of the Nail}

The nail and the special instruments were manufactured by Schobell Indústria Ltda. (Rio Claro/São Paulo/Brazil) and used in patients with complex femoral fractures. These patients were operated on with the intramedullary nail, whose characteristic was a conventional nail of Küntscher with $12 \mathrm{~mm}$ standard transversal diameter with clover leaf form modified and manufactured in 316 L stainless steel, with 12 perforations, two proximal holes in a $60^{\circ}$ inclination, and ten distal holes, giving a freedom degree of $60^{\circ}$ for the screws along the groove of the nail and its plan of symmetry, allowing orientation through the holes in a convergent or divergent direction and, thus, locking the nail in the medular canal in a lateral-lateral direction, as Figure 2 shows. The nail wall was $2.0 \mathrm{~mm}$ thick rather than $1.2 \mathrm{~mm}$ as the classic Küntschernail.

The screws were similar to the AO/ASIF type, $4.5 \mathrm{~mm}$, coiled only in their final $16 \mathrm{~mm}$.

The instruments were specially developed according to Paschoa/(27) to implant the FMRP locking nail.

Proximal locking is effected inserting two screws with the help of a proximal guide connected to the cranial end of the nail.

Distal locking is effected connecting the distal guide to the proximal guide, to determine the local where an orifice must be made in the femur lateral cortex, at the same distance of one of the more distal holes from the nail, at the height of the metaepiphyseal region. This orifice is the guide to remove a $1.5 \mathrm{~cm}$ diameter bone cylinder from the lateral cortical with the help of a special trefina. Additional curettage, at the bottom of the created defect, permits localization of the nail inside the medullary canal. Observing the nail inside the canal and the position of the proximal guide connected to the nail, a perforation of about $5 \mathrm{~cm}$ is made cranially to the defect, passing through both corticals and one of the nail orifices, where an adequately sized screw is placed. The bone cylinder is then placed in its original place, using a screw that passes through it, through the nail and the medial cortical perforation, effecting the additional distal locking and closing the defect.

In 41 patients, $1.2 \mathrm{~mm}$ wall thick nails and in 62 patients, $2.0 \mathrm{~mm}$ wall thick nails were used.
Figure 2 - General view of the FMRP locking nail system implants: A) distal portion of the nail, evidencing the different inclination where the screw can be inserted;

B) and C) nail proximal and distal portions, respectively, faces of the medial cortical of the femur; $D$ ) proximal portion with two screws in the respective holes; E) locking screws; F) and G) distal and proximal portion, respectively, faces of the femur lateral cortical. 


\section{Método}

Os cuidados aos pacientes operados com a haste bloqueada FMRP foram divididos em: pré e pós- operatório.

No período pré-operatório, os pacientes foram mantidos no leito em tração esquelética na região proximal da tíbia com aproximadamente 10 a 15 quilos. Em todos os casos, utilizou-se a chamada haste bloqueante antitelescopável desenvolvida na Universidade de São Paulo- Faculdade de Medicina de Ribeirão Preto e Escola de Engenharia de São Carlos (27).

No primeiro momento: verificação do problema clínico e confirmação da indicação da haste bloqueada (dados que subsidiam a reavaliação), por meio de parâmetros clínicos e radiográficos. Em seguida, o paciente era submetido ao procedimento de tração esquelética na tíbia, enquanto aguardava a cirurgia, em férula de Braun, começando com 10 quilogramas e aumentando o peso da tração para, 15 quilogramas, após 1 a 2 dias. A duração deve ser de pelo menos 5 dias, para evitar encurtamento excessivo, já que a tração intra-operatória é apenas manual.

Após a cirurgia os pontos da pele foram retirados em torno do décimo quinto dia. A carga sobre o membro foi aumentada progressivamente de acordo com a presença de calo ósseo observado nas radiografias de acompanhamento.

O paciente foi colocado em férula ou travesseiros, de forma a manter a flexão do quadril e do joelho próxima de $90^{\circ}$ para evitar a aderência do quadríceps em extensão, com consequente perda da flexão. Permaneceu nessa posição quase todo o tempo, durante a primeira semana, só saindo para fisioterapia. Esta começou no quarto dia, com contrações isométricas dos grupos musculares do membro inferior. Encorajou-se o paciente a deambular com andador permitindo-se carga parcial de até 20 quilos, medidos em balança.

Os pacientes foram reavaliados com pelo menos 12 meses de pós-operatório, no ambulatório de ortopedia do Hospital das Clínicas da Faculdade de Medicina de Ribeirão Preto, quando então foram submetidos a exame clínico seguido de radiografia. A avaliação de todos os casos foi feita pessoalmente pelo autor, observando os critérios de Thöresen ${ }^{(30)}$

Todos os pacientes foram acompanhados até à consolidação das fraturas, à exceção à exceção de 3 pacientes, cuja fratura consolidou, porém, com outro método de tratamento.

Para avaliação da consolidação da fratura observou-se como critérios clínicos a ausência de dor na região da fratura e a mobilidade indolor de quadril e joelho, independentemente de amplitude articular. Estabeleceu-se como critério radiográfico a formação de calo periostal, simultânea à de calo entre os fragmentos. Procedeu-se aos controles radiográficos pósoperatório imediato, com quatro semanas de evolução, com oito semanas após a cirurgia com intervalos periódicos até completar no mínimo 12 meses. Houve acompanhamento de todos os pacientes até 12 meses após a cirurgia. Os pacientes foram acompanhados em nível ambulatorial através de parâmetros clínicos

\section{Method}

The pacientes operated on with the FMRP locking nail were divided according to pre- and post-operatory care.

In the pre-operatory period, the patient were bed rested with approximately 10 to 15 kilograms skeleton traction in the tibial proximal region. In all cases, the so-called antitelescopable locking nail developed in the Ribeirão Preto College of Medicine and in the São Carlos School of Engineering, University of São Paulo ${ }^{(27)}$ was used.

In a first moment: verification of the clinical problem and confirmation of the indication for locking nailing (data which subside re-evaluation), by means of clinical and radiographic parameters. Then, awaiting surgery in Braun's ferule, the patient was submitted to tibial skeleton traction procedures starting with 10 kilos and increasing weight to 15 kilos after 1 to 2 days. Duration must be at least 5 days, to avoid excessive shortening, since the intra-operatory traction is only manual.

After surgery, sutures were removed by the $15^{\text {th }}$ day. Load on the limb was progressively increased according to the presence of callus in the follow-up radiographs.

The patients were placed on ferula or pillows, such as to maintain hip knee flexure near $90^{\circ}$ to avoid adherence of the quadriceps in extension, with consequent loss of flexure. They remained in this position during almost all the first week, leaving it only for physiotherapy, which was instituted in the fourth day, with isometric contractions of the lower limb groups of muscles. The patients were encouraged to walk using walking aids permitting partial load up to 20 kilos, measured with a scale.

The patients were re-evaluated at least 12 months after surgery, in the orthopedics ambulatory, "Hospital das Clínicas", Ribeirão Preto College of Meldicine, when they were submitted to clinical examinations and X-rays. Evaluation of all the cases was done by the author, observing the Thöresen criteria ${ }^{(30)}$.

All the patients were followed-up until fracture consolidation, with the exception of 3 whose fracture consolidated with another method of treatment.

To evaluate the fracture consolidation, clinical criteria as absence of pain in the fracture region and painless hip and knee mobility despite articular amplitude were observed. As radiographic criterion the formation of periostal callus simultaneous to the callus between the fragments. Radiographic contro/ was effected immediately after surgery, after four weeks, after eight weeks and at periodic intervals until a minimum of 12 months. The patients were followed up to 12 months after surgery. Follow-up was effected in the ambulatory using clinical and radiographic parameters. The patients were asked in relation to complaints, in particular local pain; mobility of the hip and knee joints was determined; alignment and shortening of the lesioned lower limb were also determined. Concerning the radiographic aspect, bone alignment was observed as well as the formation of the callus around the fracture.

The results of the treatment were evaluated considering the X-rays analysis, the consolidation or not of the fractures and the presence or not of angular deviation; in the clinical examination, shortening and amplitude of the hip and knee movement were considered. The data were analyzed according to the Thöresen et al. ${ }^{(30)}$ method, shown in Table 1. 
e radiográficos. O paciente era questionado em relação às queixas, em especial a dor local, era verificada a mobilidade das articulações do quadril e joelho; o alinhamento e o encurtamento do membro inferior lesado. Quanto ao aspecto radiográfico observou-se o alinhamento ósseo e a formação de calo ósseo ao redor da fratura.

Para a avaliação dos resultados do tratamento, considerou-se na análise das radiografias, a consolidação ou não das fraturas e a presença ou não de desvios angulares e, no exame clínico, a amplitude de movimento do quadril e do joelho e de encurtamento. Os dados obtidos foram analisados de acordo com o método de Thörense et al. ${ }^{(30)}$ demonstrado na Quadro 1.

\section{Quadro. 1 - Método de Avaliação para fraturas consolidadas}

\begin{tabular}{|l|c|c|c|c|}
\hline Desalinhamento (graus) & Excelente & Bom & Regular & Mau \\
\hline Varo/Nalgo & $<5^{\circ}$ & $5^{\circ}$ & $10^{\circ}$ & $>10^{\circ}$ \\
\hline Ante ou Recurvato & $<5^{\circ}$ & $10^{\circ}$ & $15^{\circ}$ & $>15^{\circ}$ \\
\hline Rotação/ Interna & $<5^{\circ}$ & $10^{\circ}$ & $15^{\circ}$ & $>15^{\circ}$ \\
\hline Rotação/Externa & $10^{\circ}$ & $15^{\circ}$ & $20^{\circ}$ & $>15^{\circ}$ \\
\hline Encurtamento (cm) & $\leq 1$ & $\leq 2$ & $\leq 3$ & $>3$ \\
\hline Flexão Joelho & $>120^{\circ}$ & $120^{\circ}$ & $90^{\circ}$ & $<90^{\circ}$ \\
\hline Deficit Extensão/Joelho & $\leq 5^{\circ}$ & $\leq 10^{\circ}$ & $\leq 15^{\circ}$ & $\leq 15^{\circ}$ \\
\hline Dor & nenhuma & leve & moderada & intensa \\
\hline
\end{tabular}

Fonte: THÖRESEN et al, 1985

Para os controles de consolidação óssea foram realizadas radiografias com 8 e 16 semanas de pós-operatório. Quando as radiografias realizadas na $8^{a}$ semana mostravam calo ósseo em quantidade satisfatória, autorizava-se carga total.

O controle radiográfico final e a reavaliação completa foram feitos com 12 meses de pós-operatório.

A consolidação da fratura foi definida como o período após a cirurgia, quando a carga total no membro era realizada sem suporte externo e era observada consolidação radiológica (34).

O retardo de consolidação foi considerado presente se, radiograficamente, não fosse demonstrada consolidação no período entre 16 a 24 semanas, após a lesão ${ }^{(34)}$.

Não consolidação foi definida como a presença de dor e movimento no foco de fratura, sem evidência radiográfica de progressão da consolidação 26 semanas após a lesão ${ }^{(34)}$.

\section{Técnica Cirúrgica}

O paciente é posicionado em decúbito lateral sobre o lado contralateral em mesa cirúrgica comum. Faz-se incisão de mais ou menos 10 centímetros, começando logo acima da ponta do trocânter maior e descendo em linha com o fêmur. A fáscia lata é aberta em linha com a incisão.

Fende-se as fibras dos glúteos médio e mínimo, dando acesso à junção do colo femoral com o trocânter maior. Dois afastadores
Table 1 - Method to evaluate consolidated fractures

\begin{tabular}{|lcccc|}
\hline Non-a lignment degrees ) & Exc ellent & Good & Regular & Bad \\
\hline Varus/valgus & $<5^{\circ}$ & $5^{\circ}$ & $10^{\circ}$ & $>10^{\circ}$ \\
\hline Ante or recurved & $<5^{\circ}$ & $10^{\circ}$ & $15^{\circ}$ & $>15^{\circ}$ \\
\hline Rotation/Internal & $<5^{\circ}$ & $10^{\circ}$ & $15^{\circ}$ & $>15^{\circ}$ \\
\hline Rotation/external & $10^{\circ}$ & $15^{\circ}$ & $20^{\circ}$ & $>15^{\circ}$ \\
\hline Shortening (cm) & $\leq 1$ & $\leq 2$ & $\leq 3$ & $>3$ \\
Knee flexure & $>120^{\circ}$ & $120^{\circ}$ & $90^{\circ}$ & $<90^{\circ}$ \\
\hline Extension Deficit/Knee & $\leq 5^{\circ}$ & $\leq 10^{\circ}$ & $\leq 15^{\circ}$ & $\leq 15^{\circ}$ \\
\hline Pain & Nome & Mild & Moderate & intense \\
\hline
\end{tabular}

Fonte: THÖRESEN et al, 1985

To control bone consolidation radiographs were taken 8 and 16 weeks after surgery. When the radiographs taken in the $8^{\text {th }}$ week showed a satisfactory callus, total load was authorized.

Final radiographic control and complete re-evaluation were effected 12 months after surgery.

Consolidation of the fracture was defined as the period after surgery when total load in the limb was carried with no external support and radiological consolidation was observed(34)

Consolidation delay was considered present if, radiographically, consolidation was not evidenced from 16 to 24 weeks after trauma(34).

Non-consolidation was defined as the presence of pain and movement in the fracture focus, with no radiographic evidence of progression of the consolidation 26 weeks after the lesion ${ }^{(34)}$.

\section{Surgical technique}

The patients are placed in lateral decubitus on the contralateral side in the usual operating table. An incision of about $10 \mathrm{~cm}$ is made, starting just above the greater trochanter tip and descending aligned with the femur. The fascia lata is opened aligned with the incision.

The maximus and minimum gluteal muscle fibers are cut, giving access to the femoral neck junction with the greater trochanter. Two afastadores de Hohmann are placed in front and behind the neck base.

Punctioning, an orifice is made at middle distance between the Hohmann afastadores, in the neck-trochanter junction. The canal is opened with a long drill. The middle point of the neck-trochanter transition is perforated by means of a punction instrument and the canal is opened. The proximal fragment is successively widened with manual reamers till $12 \mathrm{~mm}$.

The $9 \mathrm{~mm}$ reamer pushed by the motor is introduced followed by others, duly protecting the muscular fibers with a soft parts protector special for this purpose. Only the proximal fragment is reamed in this phase.

Passing of the guiding wire: an assistant supports the homolateral hemipe/vis, making contraction in the antero-superior iliac spine, while another assistant produces moderate traction with the knee and the hip bent, as they were doing the test of the anterior gaveta. The guiding wire is introduced by the proximal perforation and tentatives 
de Hohmann são colocados na frente e atrás da base do colo.

Com punção, faz-se um orifício no ponto à meia distância entre os afastadores de Hohmann e na junção do colo com o trocânter. O canal é aberto com broca longa. O ponto médio da transição colo-trocanter é perfurado por meio de instrumental do tipo punção e a seguir o canal é aberto, sendo o fragmento proximal alargado sucessivamente com fresas manuais, até atingir a espessura de 12 $\mathrm{mm}$.

Introduz-se a fresa de $9 \mathrm{~mm}$ seguida das demais, impulsionadas pelo motor e com a devida proteção das fibras musculares, com o protetor de partes moles especial para este fim. Apenas o fragmento proximal é fresado nesta fase.

Passagem do fio guia: um auxiliar sustenta a hemibacia homolateral, fazendo contratração na espinha ilíaca ântero-superior, enquanto outro faz tração moderada com o joelho e quadril fletidos, como se estivesse fazendo teste da gaveta anterior. O fio guia é introduzido pela perfuração proximal e tentativas são feitas para que este passe para dentro do canal medular distal, fazendo manobras de angulação na fratura, sob tração na forma descrita anteriormente. Se durante a redução houver dificuldade, pode ser usado o distrator $\mathrm{AO}^{(23)}$, como elemento auxiliar da redução. $\mathrm{O}$ sucesso nessas tentativas é sugerido pela sensação de atrito no interior do canal na progressão e parada firme do fio, quando encontra o osso esponjoso da metáfise distal. Ao contrário, se estiver fora do canal distal, a parada da progressão é relativamente "macia" e, usualmente, o fio protui na pele.

Se houver dificuldade na passagem a céu fechado, faz-se então um "miniacesso", que é uma incisão transversal de $3 \mathrm{~cm}$ na pele e subcutâneo na altura do foco. A fáscia lata é aberta longitudinalmente por $3 \mathrm{~cm}$, seguido de dissecção romba até o foco através do vasto lateral. Com uma das mãos, o fio guia é avançado/retraído e com a outra procura-se sentir e orientar a ponta do fio guia para dentro da abertura do canal distal.

A seguir, realiza-se a impactação do fio no osso esponjoso distal. Com o segundo fio guia, pode-se estimar até que ponto o primeiro penetrou, colocando-o lado a lado com o primeiro, externamente.

Sob tração, o comprimento da haste é estimado, colocando-se a ponta do segundo fio na ponta do trôcanter maior. O restante do segundo fio, que sobrepassa o primeiro, é o comprimento da haste que irá para dentro do canal.

Passa-se, então, em toda a extensão do ístmo a fresa em L canulada para garantir que o canal tenha pelo menos $12 \mathrm{~mm}$ em linha reta e a haste não emperre.

A haste escolhida é articulada no batedor especial e introduzida sob tração no membro, com movimentos rotatórios curtos no cabo do batedor. A haste deve ser introduzida delicadamente até cerca de $10 \mathrm{~cm}$ para fora da ferida. Manobras de angulação na fratura podem facilitar muito a introdução. Outras vezes, uma rotação de $90^{\circ}$ a $180^{\circ}$ na haste com o cabo do batedor pode vencer um bloqueio na progressão.

O batedor é desarticulado e o guia proximal é conectado à haste após a remoção do fio guia. Neste ponto, a haste deve ter sua are made in order that it passes to the inner distal medular canal, making maneuvers of angulation in the fracture, under traction as previously described. If reduction becomes difficult, an AO distractor can be used ${ }^{(23)}$ as aiding element of reduction. Success in these tentatives is suggested by the attrition sensation in the inner part of the canal when the wire progresses and firmly stops as it meets the distal metaphysis spongy bone. On the contrary, if it is out of the distal canal, the progression stop is relatively "soft" and usually the wire protui in the skin.

If the closed passage becomes difficult a "miniaccess" is made, that is, a $3 \mathrm{~cm}$ transverse incision subscutaneous at the focus point. Three $\mathrm{cm}$ are longitudinally opened in the fascia lata, following romba dissection until the focus through the lateral vastus. Using one of the hands the guiding wire is advanced/retracted and with the other its is felt and orientated inside the distal canal opening.

Afterwards, impactation of the wire is effected in the distal spongy bone. The second guiding wire allows to estimate to which point the other has penetrated, placing it externally, side by side with the first.

Under traction, the nail lenght is estimated, and the tip of the second wire is placed in the tip of the greater trochanter. The lenght of the second wire that surpasses the first is the nail lenght that is entering the canal.

In all the extension of the isthmus the tubular $L$ reamer is passed to guarantee that the canal has at least $12 \mathrm{~mm}$ in straight line and that the nail will not be detained.

The chosen nail is articulated in a special batedor and it is introduced in the limb under traction, with short rotational movements in the batedor handle. The nail must be delicately introduced till about 10 $\mathrm{cm}$ out of the wound. Angulation maneuvers in the fracture can facilitate the introduction. $A 90^{\circ}$ to $180^{\circ}$ rotation in the nail using the batedor handle may resolve when progress is blocked.

The batedor is disarticulated and the proximal guide is connected to the nail after remotion of the guiding wire. In this point, the nail must have its longitudinal opening turned to the femur lateral cortical.

The nail is introduced until its end, so as the inferior part of the proximal guide touches the tip of the trochanter. It is very important to maintain traction during this phase, only liberating it after the first proximal screw is placed avoiding excessive shortening and penetration of the nail in the knee.

One must consider the force of gravity which frequently provokes valgus deviation in the fracture, specially when it is distal in the diaphysis. To avoid this, support is given (campos dobrados) to the medial face of the thigh before encraving the nail in the metaphyseal spongy bone.

An assistant maintains, then, the proximal guide firmly articulated in the nail, exerting light pressure on the proximal guide head, while traction is maintained.

The proximal drill protector is placed in the nearest perforation of the nail axle and the first perforation is effected.

The protector is withdrawn and the size of the screw is estimated with a special measurer. The proximal guide must not be withdrawn. It orientates concerning the perforation axle.

The first proximal screw is inserted with the help of a centralizing 
abertura longitudinal voltada para a cortical lateral do fêmur.

A haste é introduzida até o final de modo que a parte inferior do guia proximal toque a ponta do trocânter. É muito importante manter a tração nessa fase, só liberando-a após a colocação do primeiro parafuso proximal, o que evita encurtamento excessivo e a penetração da haste no joelho.

Deve-se considerar aqui a ação da gravidade que provoca frequentemente desvio em valgo na fratura, especialmente quando esta é distal na diáfise. Para evitar isto, pode-se colocar suporte (campos dobrados) sob a face medial da coxa, antes de encravar a haste no osso esponjoso da região metafisária.

Um auxiliar mantém então o guia proximal firmemente articulado na haste, fazendo pressão leve sobre a cabeça em cogumelo do guia proximal, enquanto a tração é mantida.

O protetor de brocas proximal é colocado na perfuração mais próxima do eixo da haste e a primeira perfuração é feita.

O protetor é retirado e o tamanho do parafuso é estimado com o medidor especial. O guia proximal não deve ser retirado. Ele orienta com relação ao eixo da perfuração.

O primeiro parafuso proximal é inserido com ajuda de uma pinça centralizadora e aí, então, a tração pode ser liberada, pois a haste está firme no osso esponjoso distal e fixada proximalmente pelo parafuso, não havendo mais tendência a encurtamento.

Os mesmos passos são feitos para colocação do segundo parafuso proximal, só que, na hora de sua colocação, introduz-se em seu lugar o elemento de interconexão, cuja finalidade é manter o guia proximal firmemente acoplado à haste. Neste momento, o auxiliar pode liberar a pressão sobre o guia proximal que o mantém articulado à haste.

O guia distal é articulado no proximal. Faz-se duas marcas na pele, correspondentes aos extremos da área perfurada distal da haste, observando-se a calibração existente no guia distal.

O guia distal é removido. Faz-se uma incisão na face lateral da porção distal da coxa, indo de uma marca na pele até a outra. A fáscia lata é aberta em linha com a incisão e o vasto lateral é elevado para frente, com dissecção subperiostal.

Eventualmente, é necessário a cauterização dos vasos geniculares superiores. Afastadores de Hohman são colocados, expondo a face lateral do fêmur distal.

O guia distal é novamente articulado no proximal. O protetor de brocas distal é colocado de forma a ficar imediatamente proximal à marca distal e à haste escolhida do guia correspondente. O protetor é fixado levemente na cortical lateral . Muito cuidado deve ser tomado para se evitar forçar a posição imposta pelo guia distal ao protetor de brocas.

Uma perfuração é feita apenas na cortical lateral e o guia distal é removido. A seguir, fixa-se a peça centralizadora da trefina especial que é parafusada na perfuração. Com a máquina, uma "rolha óssea" (cilindro de 1,5 cm de diâmetro) é então serrada usando a trefina. Em seguida, remove-se o cilindro ósseo distal córtico esponjoso através do guia da trefina, que fora fixado anteriormente. nipper and traction can be then liberated, since the nail is firm in the distal spongy bone and proximally fixed by the screw, with no more tendency to shortening.

The same steps are followed to place the second proximal screw, however, in the moment it will be placed, the interconnection element is placed instead, with the purpose of maintaining the proximal guide firmly coupled to the nail. In this moment, the assistant can liberate pressure on the proximal guide that maintains it articulated to the nail.

The distal guide is articulated in the proximal guide. Two marks are made on the skin, corresponding to the extremities of the nail distal perforated area, observing the calibration in the distal guide.

The distal guide is removed. Na incision is done in the lateral face of the thigh distal part, from one mark on the skin to the other. The fascia lata is opened aligned with the incision and the lateral vastus is elevated forward, with subperiostal dissection.

Ocasionally, it is necessary to cauterize the superior genicular vessels. Afastadores de Hohman are placed, exposing the lateral face of the distal femur.

The distal guide is again articulated in the proximal. The distal drill protector is placed as to be immediately proximal to the distal mark and to the nail chosen of the correspondent guide chosen nail. The protector is slightly fixed in the lateral cortical. Caution must be taken to avoid forcing the position imposed by the distal guide to the drill protector.

One perforation is made in the lateral cortical and the distal guide is removed. Afterwards, the special trefina centralizing piece is fixed and screwed in the perforation. With the machine, a "bone cork" (1.5 cm diameter cylinder) is then sawed using the trefina. Then, the spongy cortical distal bone cylinder is removed through the trefina guide which had been previously fixed.

Ocasionally, additional curettage is needed at the bottom of the cavity generated by the remotion of the "bone cork", to visualize the nail inside the femur.

When the nail is visualized after remotion of the "bone cork" in the alignment of the proximal guide, a perforation is made more proximally, inclined in relation to the nail long axle, and through one of its holes. An adequately sized screw is placed in this perforation.

With the mao livre technique, a perforation is made in the medial cortical, through the nail more central hole, in the removed "cork" resultant flaw. Using an adequate sized screw, the "cork" is again placed in its original position.

After passing the distal screws, a control radiograph is taken in two incidences, AP and profile.

The interconnection element is then removed and substituted by an adequate sized screw.

The graft taken out by the reamers is placed in the focus, through the mini-incision.

The wound is closed by planes, lefting aspiring drains in the proximal and distal wounds. The drains remain 24 hours.

Final radiographic control in the operating room is made since it is still possible to visualize the proximal portion in AP, the fracture focus 
Eventualmente, há necessidade de curetagem adicional no fundo da cavidade gerada pela remoção da "rolha óssea", para visualização da haste do interior do fêmur.

Baseado na visualização da haste pela remoção da "rolha óssea" e no alinhamento do guia proximal, uma perfuração é feita mais proximalmente, inclinada em relação ao longo eixo da haste, e através de um dos furos. Coloca-se nessa perfuração um parafuso de tamanho apropriado.

Com a técnica da mão livre, uma perfuração é feita na cortical medial, através do furo mais central da haste, na falha resultante da "rolha" removida. Com parafuso de tamanho adequado, recolocase a "rolha" em sua posição original.

Após a passagem dos parafusos distais, é feito uma radiografia de controle em duas incidências, AP e perfil.

O elemento de interconexão é então removido e substituído por parafuso de tamanho apropriado.

O enxerto retirado na fresagem é colocado no foco, através da mini-incisão realizada.

A ferida é fechada por planos, deixando-se drenos de aspiração nas feridas proximal e distal. Os drenos permanecem por 24 horas.

Controle radiográfico final, ainda dentro da sala, onde deve ser possível visualizar a porção proximal em AP, o foco fraturário e o segmento distal em AP e perfil.

No presente estudo, o tempo médio do procedimento cirúrgico aos pacientes variou em torno de $72 \pm 43$ minutos (minimo 47 , máximo 169)

\section{RESULTADOS}

Foram avaliados 103 casos (101 pacientes) operados com a haste intramedular bloqueada FMRP em pacientes portadores de fraturas femorais diafisárias instáveis. Desses, 100 fraturas (97,09\%) consolidaram, em média 16,72 semanas, exceto em 3 casos que não consolidaram necessitando outro método de tratamento para obter a união óssea. Houve necessidade de se fazer a dinamização para se obter a consolidação em 7 casos de retardo de consolidação.

Das 100 fraturas analisadas, observou-se que 53 consolidaram entre 11 e 20 semanas. Entretanto, 21 e 26 fraturas ficaram, respectivamente, acima de 20 semanas e abaixo de 11 semanas, sendo que o tempo mínimo de consolidação foi de 10 semanas e o máximo de 48 semanas com média de 16,72. Na figura 3 mostra a evolução de 1 caso tratado com a haste intramedular bloqueada FMRP.
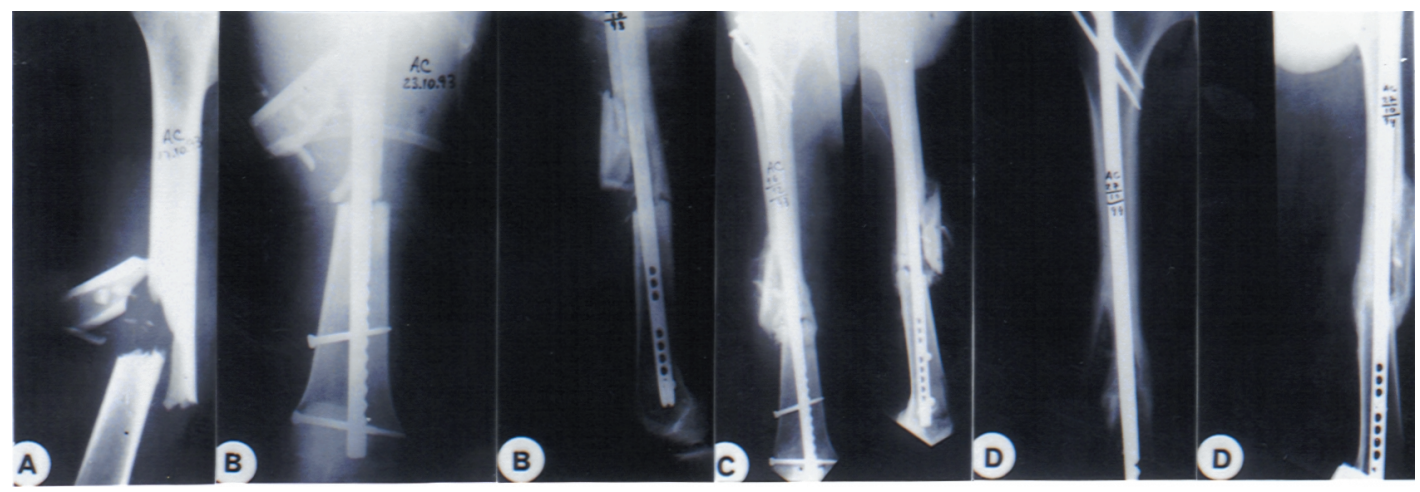

Figura 3 - Fratura cominutiva diafisária 1/3 médio do fêmur, em paciente de 31 anos de idade e acidente automobilístico;

B) controle intra-operatório; o fragmento intermediário desviado foi reposicionado por manipulação externa; C) oito semanas de pós-operatório, onde se evidencia presença de calo ósseo; D) um ano e quatro dias pós-cirurgia com fratura consolidada.

Figure 3 - Diaphyseal comminutive fracture 1/3 median of the femur, in a patient aged 31 years, victim of car accident; $B)$ intra-surgical control; the deviated intermediate fragment was repositioned by external manipulation; C) eight weeks postsurgery, presence of callus evidenced; D) one year and four days after surgery with consolidated fracture. 
O acompanhamento médio foi de 27,18 meses (mínimo de 12 e o máximo de 76 meses).

A presença de calo ósseo formando ponte entre os fragmentos foi observada radiograficamente em média de 8 semanas.

Utilizando-se o método de avaliação segundo Thörense et al. ${ }^{(30)}$ observou-se que o resultado geral da pesquisa registrou $87 \%$ de excelentes e bons.

O tempo de pós-operatório máximo foi 6 anos e 4 meses, média de 2 anos e 4 meses e mínimo de 12 meses.

A deambulação com auxílio de muletas e carga parcial no membro operado foi permitida nos primeiros dias de pósoperatório e após 8 semanas. Dependendo do aparecimento do calo ósseo radiográfico e o exame clínico de estabilização da fratura, foi autorizado marcha com carga total.

Com relação à capacidade da marcha, 53 (51,5\%) podiam caminhar ininterruptamente mais de $5 \mathrm{~km} ; 33$ (32\%) podiam caminhar entre 1 a 5km; 10 (9,7\%) entre 100 e 1000m e 4 $(3,9 \%)$ conseguiam caminhar menos de $100 \mathrm{~m}$ todos por problemas outros do aparelho locomotor e $3(2,9 \%)$ casos não analisados.

Em se tratando de dor, 55 (53,4\%) não tinham dor alguma; 41 (39,8\%) tinham dor leve relacionada a esforço ou mudança de clima; 4 (3,9\%) dor moderada, aos esforços, relacionada à lesão das partes moles por ocasião do trauma e 3 (2,9\%) não analisados.

Com relação ao uso do membro inferior, 80 (77,7\%) tinham função normal, sem diferença em relação ao lado sadio; 14 (13,6\%), 3/4 da função; 4 (3,9\%), metade da função normal; $2(1,9 \%)$, menos da metade normal e 3 (2,9\%) não analisados. No que diz respeito ao retorno à atividade exercida antes do trauma, $70(67,9 \%)$ voltaram às atividades originais no mesmo nível de atuação; 21 (20,4\%) tinham restrições leves; 5 (4,9\%) tinham restrições moderadas, 4 (3,9\%) estavam incapacitados para as atividades, apresentando dificuldade para andar e 3 (2,9\%) não analisados.

Com relação à opinião do médico, 81 (78,6\%) foram classificados como excelentes, 15 (14,6\%) como bons, 3 (2,9\%) como regulares, 1 (0,97\%) como mau e 3 (2,9\%) casos não analisados.

\section{Complicações}

Entre as complicações, verificou-se que 7 (6,80\%) fraturas com a haste bloqueada FMRP apresentaram retardo de consolidação, evoluindo para formação do calo ósseo após a dinamização com a retirada dos parafusos de bloqueio da haste.

O encurtamento foi muitas vezes proposital, nos casos de intensa cominuição, para facilitar a consolidação em fraturas cominutivas, quando se empregou o bloqueio dinâmico para facilitar a consolidação. O encurtamento médio foi de 1,00 \pm 0,99 cm (mínimo de 0,5 e máximo 4,0 cm). Este ocorreu
Mean follow-up was 27.18 months (minimum 12, maximum 76 months).

The presence of callus forming a bridge between the fragments was radiographically observed after 8 weeks on average.

Using the evaluation method according to Thörense et al. ${ }^{(30)}$ it was observed that the general result registered $87 \%$ of excellent and good results.

The maximum post-operatory period was 6 years and 4 months, average 2 years and 4 months and minimum 12 months.

Walking with crutches and partial load on the operated on limb was allowed in the first days after surgery and after 8 weeks. Depending on the appearance callus in the X-rays and the clinical examination of the fracture stabilization, walking with total load was permitted.

Concerning capacity of march, 53 (51.5\%) could walk continuously more than $5 \mathrm{~km}$; 33 (32\%) from 1 to $5 \mathrm{~km} ; 10$ (9.7\%) from 100 to 1000 $\mathrm{m}$, and 4 (3.9\%) less than $100 \mathrm{~m}$ due to other locomotion problems and $3(2.9 \%)$ due to non-analyzed cases.

Concerning pain, 55 (53.4\%) had no pain; 41 (39.8\%) had mild pain related to effort or change of weather; 4 (3.9\%) moderate pain with effort, related to lesioned soft parts due to the trauma, and 3 (2.9\%) were not analyzed.

Concerning the use of the lower limb, 80 (77.7\%) had normal function, with no differences in relation to the healthy side; 14 (13.6\%) $3 / 4$ of the function; 4 (3.9\%) half of the normal function: 2 (1.9\%) less than half of the normal function, and $3(2.9 \%)$ were not analyzed.

Concerning resuming the activities exerted before the trauma, 70 (67.9\%) resumed the same level of their original activities; 21 (20.4\%) had mild restrictions; 5 (4.9\%) moderate restrictions, 4 (3.9\%) were disabled, presenting difficulty to walk, and $3(2.9 \%)$ were not analyzed.

In the physician's opinion, 81 (78.6\%) results were considered excellent, 15 (14.6\%) good, 3 (2.9\%) regular, 1 (0.97\%) bad, and 3 (2.9\%) were not analyzed.

\section{Complications}

Among the complications, 7 (6.8\%) fractures treated by FMRP locking nailing presented delay in the consolidation, evolving to form callus after dynamization with withdrawal of the screws which locked the nail.

Shortening was frequently purposeful, in the cases of intense comminution, to ease the comminutive fractures consolidation when dynamic locking was used to facilitate consolidation. Mean shortening was $1.00 \pm 0.99 \mathrm{~cm}$ (minimum 0.5 and maximum 4.0). This occurred in 81 patients, among which 35 had less malleolar spine lenght in the fractured side than in the contralateral side, from 0.6 to $1.5 \mathrm{~cm}$. However, 23 patients presented less than $0.6 \mathrm{~cm}$ and other 23 more than $1.5 \mathrm{~cm}$ shortening,

Among the systemic complications, in 91, none; fat embolism in 4; pulmonary embolism in 2; pneumonia in 3; deep venous thrombosis (TVP) in 1, and respiratory insufficiency in 1.

Technical errors were obsenved intra-operatively.

Concerning the reduction quality, only 19 (14.71\%) did not present any deviation; 81 (61.76\%) presented shortening; 4 (2.94\%) were 
em 81 pacientes, dos quais 35 possuíam comprimento espino maleolar menor do lado da fratura do que do lado contralateral com variação de 0,6 a 1,5 cm. Porém, 23 pacientes permaneceram abaixo de $0,6 \mathrm{~cm}$ e 23 pacientes acima de $1,5 \mathrm{~cm}$ de encurtamento.

Entre as complicações sistêmicas, em 91 nenhuma; embolia gordurosa em 4; embolia pulmonar em 2; pneumonia em 3; trombose venosa profunda (TVP) em 1 e insuficiência respiratória em 1.

Foram observadas algumas falhas técnicas ocorridas no intra-operatório.

Com relação à qualidade da redução obtida, apenas 19 $(14,71 \%)$ não tinham desvio algum; 81 (61,76\%) apresentavam encurtamento; 4 (2,94\%) apresentavam valgo, 1 menor que $5^{\circ}$ e 3 igual a $10^{\circ}$. Ocorreu em 4 varos com uma média de $7^{\circ}$ (máximo de $10^{\circ}$ ). Em 2 destes casos, ocorreram no 1/3 distal do fêmur; um, no 1/3 proximal e 2, no $1 / 3$ médio da diáfise; $4(3,68 \%)$ varo um menor que $5^{\circ}$ quatro igual a $10^{\circ}$. Isto ocorreu em 5 pacientes com uma média de $6^{\circ}$ (máximo de $10^{\circ}$ ). Três destes ocorreram no $1 / 3$ proximal da fratura; dos dois restantes, um em paciente operado com 33 dias após o acidente e outro fratura do $1 / 3$ distal e 10 $(45,38 \%)$ deformidades torcionais menores que $15^{\circ}$ (máximo de $15^{\circ}$ em apenas um caso) em 7 torções externas e 3 torções internas (mais de uma opção). O varismo foi encontrado em 4; valgismo em 4 pacientes e antecurvato de $5^{\circ}$ em 1 paciente. Este último observando-se a haste intramedular que entortou.

A rotação na coxo-femoral foi normal em 93 (90,29\%) pacientes. Com restrição pequena de no máximo $10^{\circ}$. Houve ligeiro desvio torcional em 10 casos que variou de menos de $4^{\circ}$ a $10^{\circ}$

Quanto à mobilidade do joelho, 93 casos não apresentaram limitação da flexo-extensão, enquanto 7 casos tiveram limitação de movimento de flexão, respectivamente 0 a $110^{\circ}$ e 0 a $40^{\circ}$. Somente em um caso houve limitação de flexão, que permaneceu de 0 a $40^{\circ}$.

No pós-operatório, ocorreram 7 casos de infecção, sendo 4 $(6,8 \%)$ suspeitas e $3(2,91 \%)$ estabelecidas. Tanto uma quanto a outra foram resolvidas através de drenagem, desbridamento, irrigação contínua e antibioticoterapia obtendo-se com esse tratamento uma boa evolução, com exceção de um caso de fratura exposta grau II e que três dias antes da osteossíntese com haste bloqueada foi feito desbridamento e irrigação contínua e mesmo com este cuidado evoluiu para uma infecção profunda e, após 12 meses de evolução com a haste, ao fazer-se a retirada da haste mais limpeza cirúrgica, ocorreu refratura, sendo então indicado como opção de tratamento fixador externo.

Dos 103 casos estudados, 92\% não tiveram complicações locais, enquanto $10 \%$ apresentaram as seguintes complicações: hematoma em 3, suspeita de infecção e em valgus, 1 less than $5^{\circ}$ and 3 equal to $10^{\circ} ; 4$ varus on average $7^{\circ}$ (maximum $10^{\circ}$ ). In 2 cases in the femur distal 1/3; one in the proximal $1 / 3$ and 2 in the middle $1 / 3$ of the diaphysis; 4 (3.68\%) varus one less than $5^{\circ}, 4$ equal to $10^{\circ}$. This occurred in 5 patients with on average $6^{\circ}$ (maximum $10^{\circ}$ ). Three of these occurred in the fracture proximal 1/3; in the other two, one in a patient operated on 33 days after the accident and the other with a distal 1/3 fracture, and 10 (45.38\%) torsion deformities less than $15^{\circ}$ (maximum $15^{\circ}$ in only one case); 7 external torsions, and 3 internal torsions (more than one option). Varism was found in 4 , valgism in 4 patients, and $5^{\circ}$ antecurvatus in one patient. This last patient observing the intramedullary nail which has bent.

Rotation of the hip was normal in 93 (90.29\%) patients. With small restrictions of no more than $10^{\circ}$. There was mild torsional deviation in 10 cases, less than $4^{\circ}$ to $10^{\circ}$.

Concerning mobility of the knee, 93 cases did not present flexureextension limitation, while 7 cases presented flexure limitation, respectively 0 to $110^{\circ}$ and 0 to $40^{\circ}$ Only one case presented flexure limitation from 0 to $40^{\circ}$.

In the post-operatory period, 7 cases of infection, 4 (6.8\%) suspected and 3 (2.91\%) established, were observed. Both were treated with drainage, débridement, continuous irrigation and antibioticotherapy with good evolution, with the exception of one case of grade II open fracture in which three days before the locking nail osteosynthesis, débridement and continuous irrigation were done, but even with these precautions, it evolved to a deep infection and after 12 months, when the nail was withdrawn and surgical cleaning was effected, re-fracture occurred and the external fixator was indicated as the option.

Among the 103 studied cases, 92\% did not show local complications, while $10 \%$ showed the following complications: hematoma in 3, suspected infection with favorable evolution in 4, and established infection in 3; more than one patient presented more than one local complication.

Late complications were: in 7 (6.7\%) cases, rupture and bending of the nails demanding substitution, in only 3 (2.91\%) cases due to fall and a second motorcycle accident; 8 (7.77\%) cases, rupture or bending of the screws evolving to consolidation with no need of change; in 6 (4.59\%) cases, a re-osteosynthesis was necessary due to rupture and bending of the nail and screws. There were also 12 cases with the screws out of the orifices, but this had no implication related to consolidation. Figures 4 and 5 show the evolution of the patients treated with the FMRP intramedullary locking nail.

The status of the implants on re-evaluation was: no alteration in 82; removed in 19; dynamized in 7, and changed in 5. 
evolução favorável em 4 e infecção estabelecida em 3, sendo que havia paciente com mais de uma complicação local. As complicações tardias foram: 7 (6,8\%) quebras e vergamentos de hastes necessitando troca, o que só ocorreu em 3 $(2,91 \%)$ casos que foi por queda e novo acidente de motocicleta; em 8 (7,77\%) quebra ou vergamento dos parafusos, com evolução para consolidação sem necessidade de troca; em 6 (4,59\%) foi necessário reosteossíntese por motivo da quebra e vergamento da haste e parafusos. Também houve 12 casos de parafusos fora do furo, mas não trouxeram nenhuma implicação de ordem de consolidação. A Figura 4 e 5 mostram a evolução de pacientes tratados com a haste intramedular bloqueada FMRP.

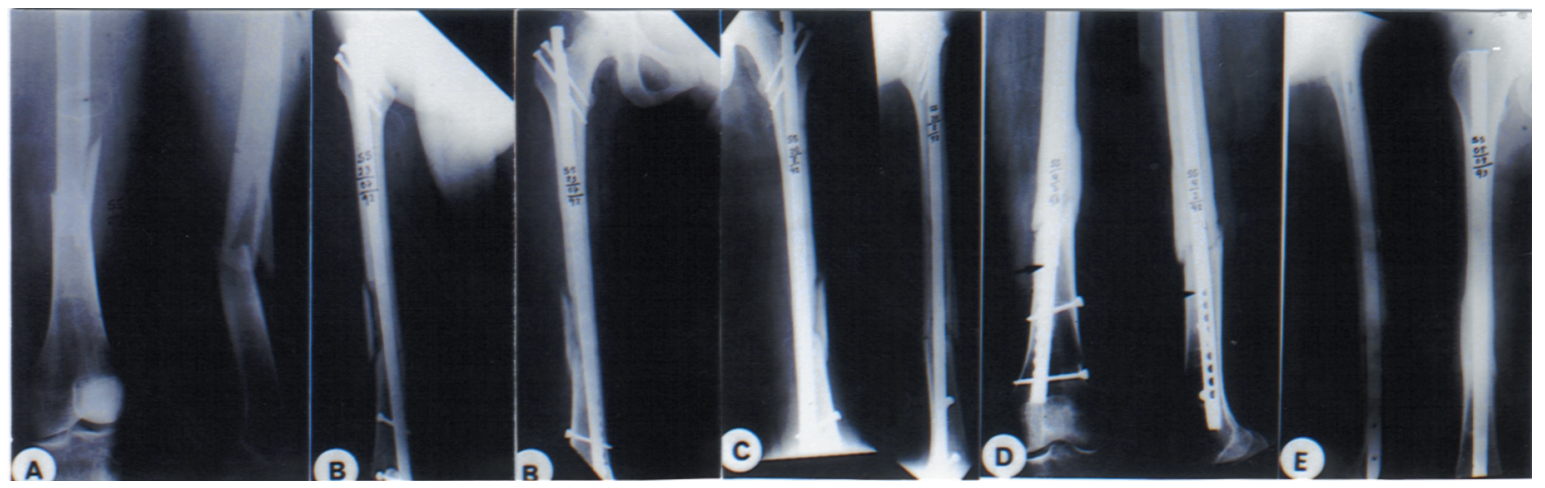

Figura 4 - Fratura cominutiva do 1/3 distal do fêmur em paciente de 29 anos de idade, vítima de acidente; A) Pré- operatório;

B) pós- operatório de 4 semanas; C) 8 semanas de pós- operatório mostra formação de calo ósseo; D) 28 semanas se observa sinais de quebra da haste, na ponta.; E) após a troca da haste, fratura consolidada.

Figure 4 - Comminutive fracture of the femur distal 1/3 in a 29 year-old patient victim of accident; A) pre-operatory; B) 4 weeks post-surgery; C) 8 weeks post-surgery showing formation of the callus; D) 28 weeks after with signs of rupture in the nail, in the tip; E) after changing the nail, consolidated fracture.

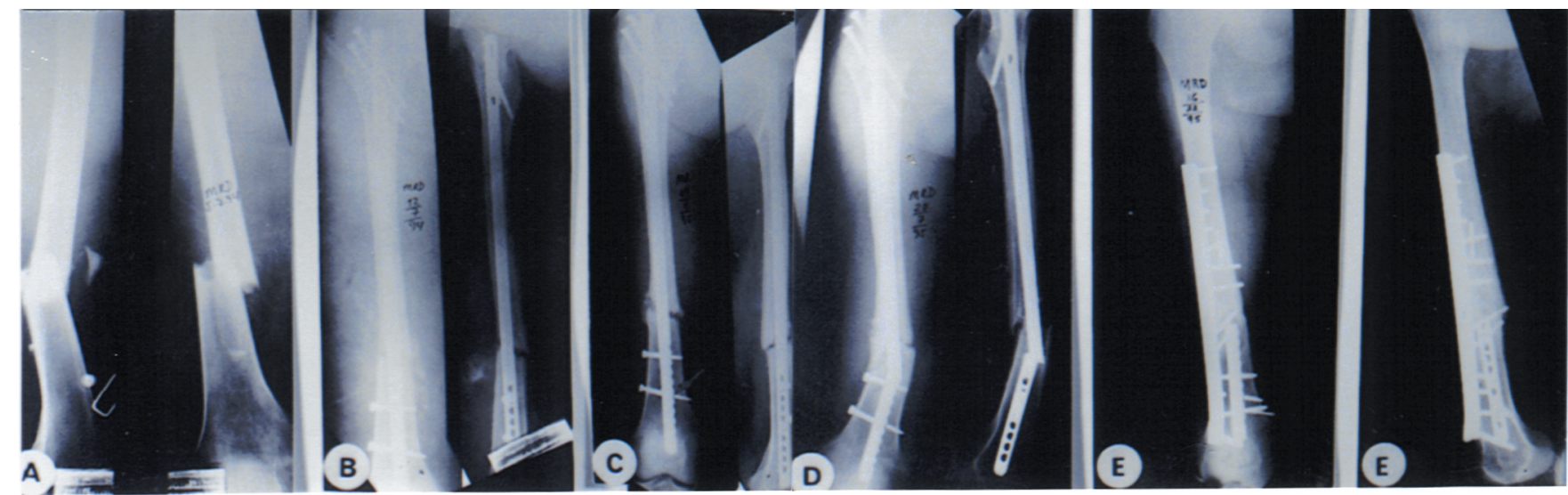

Figura 5 - Fratura do 1/3 distal do fêmur em paciente de 19 anos de idade, vítima de acidente; A) Pré- operatório; B) Pós-operatório imediato; C) 20 semanas de pós- operatório mostra quebra do parafuso distal na ponta da seta; D) 12 meses de pós-operatório mostra quebra da haste; E) 16 meses; mostra troca do implante aos 4 meses de pós-operatório da troca com retenção do fragmento distal da haste, fratura consolidada.

Figure 5 - Femur distal 1/3 fracture in a 19 year-old patient victim of accident; A) pre-operatory; B) immediate post-operatory; C) 20 weeks post-surgery showing rupture of the distal screw in the tip of the arrow; D) 12 months post-operatory showing rupture of the nail; E) 16 months; showing change of the implant 4 months after change surgery with retention of the nail distal fragment, consolidated fracture. 


\section{DISCUSSÃO}

A técnica cirúrgica utilizada nesse estudo (27) apresenta um método que confere estabilização do foco de fratura, e permite, não só a sua consolidação, como também a mobilização do paciente, geralmente politraumatizado. Favorece a preservação, ao máximo, de vascularização dos fragmentos fraturários e facilita a formação do calo ósseo, usando material simples e sem sofisticações. A facilidade da técnica, torna-a acessível à maioria dos serviços do país, com baixo índice de complicações.

Winquist et al. e Wiss et al. ${ }^{(33,34)}$ relataram suas observações quanto à tração pré-operatória. No estudo desenvolvido por Paschoal(27) ela foi considerada importante, principalmente, no que se refere ao emprego de forte tração, utilizando-a com variação em torno de 5 a 10 quilos na região proximal da tíbia. Observou-se, ainda, maior facilidade de redução da fratura no período intraoperatório, registrando-se apenas um paciente que necessitou de 15 quilos para promover a distração dos fragmentos, porque o mesmo apresentava um grande desenvolvimento da musculatura do quadríceps.

A tração esquelética pré-operatória, nesse estudo, foi em média de 5 a 10 dias. Ela é recomendada como tratamento inicial de fraturas femorais e inclusive as fraturas expostas em pacientes não politraumatizados. Brumback et al. ${ }^{(4)}$ e Winquist et al. ${ }^{(33)}$ não relataram em seu estudo tais complicações, afirmando que, nos casos em que os pacientes não são politraumatizados e que as fraturas femorais não são consideradas isoladas, a abordagem inicial deve ser feita por meio de forte tração esquelética. Apesar dessas afirmações, optou-se nesta pesquisa em submeter à tração préoperatória, os pacientes não politraumatizados, especialmente os pacientes hospitalizados na UTI, que tiveram a cirurgia retardada dificultando a redução da fratura intra-operatório por causa da presença do calo ósseo que teve que ser desfeito para se obter boa redução.

Quanto ao miniacesso à fratura, referencia-se os achados de Mattos et al. ${ }^{(20)}$, Rodrigues \& Ortiz ${ }^{(28)}$ e Morelli et al.(21) afirmam que o miniacesso não interfere no resultado final da operação, especialmente, no tocante à infecção. No caso estudado, o miniacesso à fratura, durante a operação, possibilitou algumas vantagens para melhor desempenho do cirurgião. Pôde-se constatar encurtamentos, alterações de rotação e, principalmente, orientar a passagem do fio guia no fragmento distal. Além disso, a não utilização de intensificador de imagem, durante a operação, evitou falsas interpretações, principalmente as rotacionais e a exposição ao raio $X$.

Nesse estudo, obteve-se 97,09\% de consolidação óssea. Essa porcentagem é similar àquelas obtidas por vários autores que obtiveram uma taxa de consolidação em torno de 96 a $100 \%(2,9,14,17,30,34)$. Alguns autores como Böhler ${ }^{(3)}$ defendem a técnica fechada, pois levaria a menor tempo de consolidação da fratura, menor índice de infecção, retorno funcional mais precoce e menor tempo de internação.

\section{DISCUSSION}

The surgical technique used in this study ${ }^{(27)}$ presents a method that provides stabilization of the fracture focus and allows not only its consolidation but also the mobilization of the patient, in general polytraumatized. It favors maximum preservation of the fractured fragments vascularization and facilitates bone callus formation, using simple materia/ without sophistication. The easiness of the technique makes it accessible to most of the country services, with a low index of complications.

Winquist et al. e Wiss et al. ${ }^{\left({ }^{33}, 34\right)}$ reported their observations concerning pre-operatory traction. In the study developed by Paschoal(27), it was considered important mainly in what concerns the use of strong traction, using about 5 to 10 kilos in the tibial proximal region. It was also observed more easiness to reduce the fracture in the intra-operatory period, registering only a patient who needed 15 kilos to promote distraction of the fragments, since he presented great development of the quadriceps muscles.

Pre-operatory skeleton traction, in this study, was effected on average from 5 to 10 days. It is recommended as the initial treatment for femoral fractures including open fractures in non-polytraumatized patients. Brumback et al. ${ }^{(4)}$ and Winquist et al. ${ }^{\left({ }^{(3)}\right)}$ did not report such complications in their study, stating that, in the cases in which the patients are not polytraumatized and the femoral fractures are not considered isolated, the initial approach must be by means of strong skeleton traction. In spite of that, this study chose the pre-operatory traction to non-polytraumatized patients specially inpatients in the ITU who had their surgeries retarded making difficult the reduction of the fracture during operation because of the presence of the bone callus which had to be undone in order that a good reduction was obtained.

Considering the mini-access to the fracture, we praise Mattos et al. ${ }^{(20)}$, Rodrigues \& Ortiz ${ }^{(28)}$ and Morelli et al. ${ }^{(21)}$ findings. They state that mini-access does not interfere in the final result of the surgery, particularly concerning infection. In the studied case, the mini-access to the fracture, during the operation, possibilitated some advantages for a better performance of the surgeon. It was possible to determine shortenings, rotation alterations and, mainly, orientate the passage of the guiding wire in the distal fragment. Besides that, the non-utilization of the image intensifier during the operation avoided false interpretations, mainly the rotational, and exposition to X-rays.

In this study, 97.09\% bone consolidation was obtained. This percentage is similar to the obtained by several authors with a consolidation rate from 96 to $100 \%^{(2,9,14,17,30,34)}$. Some authors as Böhler ${ }^{(3)}$ defend the closed technique, since less time for fracture consolidation would be necessary, and lower index of infection, earlier resuming of functions and shorter stay in hospital would be obtained.

Wu \& Shih ${ }^{(35)}$ reported 7\% incidence of rotational alteration using intramedullary locking nailing.

In this study, 4 cases of valgus deviation were observed, with segmental (1), comminutive (1) and segmental (2) fractures, all types $B$ and $C$. They presented valgism of $10^{\circ}, 8^{\circ}, 4^{\circ}$ and $4^{\circ}$, respectively. Valgisms of the mentioned cases were not considered clinically and 
Wu \& Shih ${ }^{(35)}$ relataram 7\% de incidência de alteração rotacional utilizando hastes intramedulares bloqueadas.

No presente estudo, foram observados 4 casos de desvio em valgo, com fraturas segmentar (1), cominutiva (1) e segmentares (2) respectivamente, sendo que todas eram do tipo B e C. Elas apresentaram um valgismo respectivamente de $10^{\circ}, 8^{\circ}, 4^{\circ}$ e $4^{\circ}$. Os valgismos dos casos citados não foram considerados clínica e funcionalmente significantes.

Das 103 fraturas femorais diafisárias, apenas 97 foram submetidas à fixação interna com haste intramedular bloqueada FMRP estática e 6 dinâmicas. Brumback et al. ${ }^{(4)}$ relataram que cerca de $10 \%$ de interpretações errôneas podem ocorrer na leitura das radiografias pré-operatórias e na fluroscopia operatória. Brumback et al. ${ }^{(5)}$ afirmaram que a dinamização preconizada inicialmente por Wiss et al. ${ }^{(34)}$, após 6 semanas da osteossíntese estática, não é fator importante na evolução do processo de consolidação e poderá acarretar riscos de instabilidade nas fraturas ${ }^{(30)}$. No presente estudo, pareceu que a dinamização contribuiu na consolidação das fraturas, pois a haste, em 7 casos, foi dinamizada pela retirada dos parafusos. Esses casos apresentavam características hipertróficas de retardo de consolidação e falta de contato do foco de fratura. Das 97 fraturas que permaneceram com hastes intramedulares bloqueadas estáticas, apenas 87 consolidaram com a haste FMRP estática até os 12 meses de pós-operatório, enquanto que 7 consolidaram após a dinamização pela retirada dos parafusos e as 3 restantes consolidaram com outro método de tratamento.

Acredita-se que a dinamização deva ser utilizada somente naqueles casos onde o fator biológico encontra-se representado por deficiência do calo ósseo. Discorda-se, pela experiência, de Kempf et al. ${ }^{(15)}$ que sugerem a dinamização entre 8 a 12 semanas, enquanto Brumback et al. ${ }^{(5)}$ prefere a dinamização após 12 semanas para evitar encurtamento. Dinamizou-se 7 pacientes das 94 estáticas com variação entre 12 e 40 semanas; todas eram fraturas do tipo C cominutivas e segmentar e evoluiram para consolidação. Das 103 fraturas submetidas à fixação interna com haste intramedular bloqueada, 97 foram estáticas. Ainda com relação à dinamização, optou-se por 4 casos de fraturas que apresentaram quebra dos parafusos distais resultando retardo de consolidação e para que a fratura seguisse sua consolidação normal teve-se que optar pelo procedimento de dinamização.

Um fato importante da utilização da haste $\operatorname{FMRP}^{(27)}$ é a não disponibilidade de intensificador de imagem na maioria dos hospitais nacionais, para auxiliar durante a operação. E essa é uma das principais razões da não utilização de hastes intramedulares bloqueadas, no Brasil. Portanto, recomenda-se a utilização da haste FMRP para suprir a falta de disponibilidade de acesso à alta tecnologia.

Na utilização dos intensificadores de imagens deve-se considerar: níveis de exposição gonadal; radiação de pacientes submetidos à cirurgia de fixação de fraturas femorais, com hastes intramedulares bloqueadas. Corroboram essa discussão os estudos de Kwong et al. ${ }^{(19)}$ ao constatarem que, após exposição média de 5 minutos, functionally significant.

Among the 103 diaphyseal femoral fractures, static internal fixation with FMRP intramedullary locking nailing was effected in 97 cases and dynamic in 6. Brumback et al. ${ }^{(4)}$ reported that approximately $10 \%$ of erroneous interpretations can occur when reading the pre-operatory radiographs and during operatory fluoroscopy. Brumback et al. (5) stated that dynamization recommended initially by Wiss et al. ${ }^{\left({ }^{(4)}\right.} 6$ weeks after static osteosynthesis is not an important factor in the consolidation process evolution and can cause risk of instability to the fractures ${ }^{(30)}$. In this study, it apperead that dynamization contributed to the consolidation of the fractures since the nail, in 7 cases, was dynamized by screw withdrawal. These cases presented hyperthrophic characteristics of consolidation delay and lack of contact in the fracture focus. Among the 97 fractures which remained with static intramedullary locking nails, only 87 consolidated with the static FMRP nail until 12 months post-surgery, while 7 consolidated after dynamization by screw withdrawal and other 3 consolidated with another method of treatment.

It is believed that dynamization should be used only in the cases where the biologic factor is represented by bone callus deficiency. The experience promotes disagreement concerning Kempf et al. (15) who suggest dynamization from 8 to 12 weeks while Brumback et al. ${ }^{(5)}$ prefer dynamization after 12 weeks to avoid shortening. Among the 94 static, seven patients were dynamized from 12 to 40 weeks; all of them were comminutive and segmental fractures type $C$ and evolved till consolidation. Among the 103 fractures submitted to internal fixation with the intramedullary locking nail, 97 were static. In relation to dynamization, the option was 4 cases of fractures that presented rupture of the distal screws resulting in a consolidation delay, and in order that the fracture followed its normal consolidation it was necessary to choose the dynamization procedure.

An important fact concerning the FMRP nail utilization ${ }^{(27)}$ is the non-availability of image intensifiers to aid during the operation in most of the national hospitals. That is one of the main reasons of the non-utilization of intramedullary locking nailing in Brazil. Thus, the utilization of the FMRP nailing is recommended to solve the difficulty to access high technology.

In the utilization of the image intensifiers one must consider: gonadal exposition levels; radiation on patients submitted to femoral fracture fixation surgery using intramedullary locking nails. The studies of Kwong et al ${ }^{(19)}$ contribute to this argument since they observed that after a five-minute exposition, the radiation levels were statistically significant, justifying the use of gonadal protectors during surgery. Other authors studied alternative techniques aiming to reduce exposition to radiation through distal fixation with only one screw ${ }^{(13,28,31)}$.

The distal locking technique aided by the bone cylinder remotion, introduced in Brazil by Paccola \& Paschoa/(26) avoids the high cost of the investment in image intensifiers, since almost all existent locking nails in the market demanded the use of these intensifiers. Fernandes ${ }^{(10)}$ outlines that the advantages in using that instrument lead us to underestimate the radiation consequences for the patient being operated on. The staff is also unprotected since the effects 
os níveis de radiação eram estatisticamente significantes, justificando o uso de protetores gonadais durante o ato operatório. Outros autores estudaram a técnica alternativa no propósito de diminuir a exposição de radiação através da fixação distal por apenas um parafuso $^{(13,28,31)}$.

A técnica de travamento distal auxiliado com a remoção de cilindro ósseo, introduzida no Brasil por Paccola \& Paschoal ${ }^{(26)}$, pode dispensar o alto custo do investimento na aquisição de intensificadores de imagens, uma vez que até então quase todas as hastes bloqueadas existentes no mercado requeriam o uso desses intensificadores. Fernandes ${ }^{(10)}$ ressalta que a comodidade proporcionada por esse instrumento leva a subestimar as consequências da radiação no paciente que está sendo operado. O pessoal da equipe fica, em sala, desprotegido, enquanto os efeitos produzidos pela propagação da radiação expandem-se em outras salas operatórias, além do efeito que os raios podem provocar na equipe cirúrgica com a chamada irradiação secundária. Atualmente, existem pelo menos dois métodos distintos para a colocação dos parafusos de bloqueio distal do fêmur. Um método utiliza a colocação de guia externo conectado à haste intramedular, para localização dos orifícios distais, princípio no qual também nos baseamos. O problema é que a mobilidade da guia e a deformação da haste dentro do canal falseiam a colocação percutânea dos parafusos $^{(1)}$.

Existem também as guias para a colocação percutânea dos parafusos com radioscopia ${ }^{(31)}$, que evitam a exposição das mãos à radiação, mas também são de dificil execução(1).

A colocação divergente dos parafusos distais de travamento da haste possibilita maior estabilidade ao conjunto(24). Embora a haste tenha diâmetro fixo de $12 \mathrm{~mm}$ é comprovadamente mais resistente mecanicamente quando comparada a hastes femorais bloqueadas AO-ASIF do mesmo diâmetro, inclusive com relação à resistência do primeiro orifício de bloqueio distal(25).

Com referência à taxa de infecção, a infecção suspeita foi de 4 (3,88\%) e 3 (2,91\%) infecção estabelecidas. Esse percentual pode ser considerado baixo comparado com a literatura que analisa do ponto de vista do foco de fratura fechado(3). Em outras direções, Kovacs et al. ${ }^{(18)}$ demonstraram que a incidência de infecção no tratamento intramedular da fratura de fêmur a foco aberto aumentava: com o tempo de permanência hospitalar antes da cirurgia; com múltiplos traumas associados; com fraturas expostas e quando dois destes fatores estavam associados. As 8 fraturas infectaram devido serem oriundas de fratura exposta tratada inicialmente sob tração e desbridamento e irrigação contínua por 7 dias.

A taxa de infecção estabelecida foi de 2,91\% e 3,88\% de infecção suspeita. Todas evoluiram para cura após tratamento por drenagem, irrigação contínua, desbridamento e consolidaram com a haste.

Houve outros problemas com o mau alinhamento, semelhante aos trabalhos citados por Johnson et al. ${ }^{(14)}$, mas a variação de movimentos do joelho foi melhor na presente série. O sucesso não foi tão bom quanto o de Kovacs et al. ${ }^{(18)}$ em prevenir encurtamento menor que $2,5 \mathrm{~cm}$ e má rotação mais que $15^{\circ}$. As fraturas do 1/3 produced by radiation propagation reach other operating rooms, not to mention the effect that the rays can cause to the surgical team with the so-called secondary irradiation. Nowadays, there exist at least two distinct methods to insert distal locking screws in the femur. One method uses placement of an external guide connected to the intramedullary nail, to localize the distal orifices, a principle we also base ourselves. The problem is that guide mobility and the nail deformation inside the canal disrupt the percutaneous placement of the screws ${ }^{(1)}$.

There also exist guides for percutaneous placement of the screws with radioscopy ${ }^{(31)}$ avoiding exposition of the hand to radiation, but this method is also difficult to perform ${ }^{(1)}$.

Divergent placement of the distal screws to lock the nail possibilitates greater stability ${ }^{(24)}$. Though the nail has a $12 \mathrm{~mm}$ fixed diameter, it is proven that it is mechanically more resistant when compared to the femoral AO-ASIF locking nails of the same diameter, also considering the resistance of the distal blocking first orifice ${ }^{(25)}$.

Concerning the infection rate, suspected infections were 4 (3.88\%) and established infections were 3 (2.91\%). This percentual can be considered low as compared with the literature that analyzes under the point of view of the closed fracture focus ${ }^{(3)}$. Focusing the matter differently, Kovacs et al. ${ }^{(18)}$ demonstrated that the infection incidence increased in the intramedullary treatment of femur fractures with open focus: with duration of stay in hospital before surgery, with multiple traumas associated to open fractures, and when two of these factors were associated. The 8 fractures were infected since they were open fractures treated under traction and débridement and continuous irrigation during 7 days.

The established infection rate was $2.91 \%$ and suspected infection $3.88 \%$. All of them evolved to cure after treatment with drainage, continuous irrigation, débridement and showed consolidation with the nail.

There were other problems concerning bad alignment, similar to those mentioned by Johnson et al. ${ }^{(14)}$; however, the knee range of movement was better in this series. Success was not so good as Kovacs' et al. ${ }^{(18)}$ in preventing shortenings less than $2.5 \mathrm{~cm}$ and bad rotation superior to $15^{\circ}$. Fractures of the distal third of the femur are particularly prone to develop bad axial alignment. This was not observed by Johnson et al. ${ }^{(14)}$. In this study, 4 fractures with less and 4 with more varus equal to $15^{\circ}$ resulted, as well as 10 femoral torsions below $10^{\circ}$. In spite of the precautions with fracture reduction there was a mean shortening of $1.23 \mathrm{~cm}$ (minimum 0,5, maximum $4 \mathrm{~cm}$ ). The cases which presented shortening and rotational deviation were, respectively, comminutives and spiral fractures according to Winquist \& Hansen ${ }^{(32)}$ though the locking nail is the best indication for these fractures.

Shortening of the femur from 0.5 to $4 \mathrm{~cm}$ was found in 81 cases. Shortening equal to $4 \mathrm{~cm}$ was also reported by Thörensen et al. (30) which presented results from 2.1 to $9 \mathrm{~cm}$, while Wiss et al. ${ }^{(34)}$ from 1 to $2 \mathrm{~cm}$. In this study only one fracture evolved to a $4 \mathrm{~cm}$ shortening. Bresides that, femur shortening from 0.5 to $3 \mathrm{~cm}$ was found in 80 fractures. The patient with $4 \mathrm{~cm}$ shortening evolved with almost $2 \mathrm{~cm}$ 
distal do fêmur são particularmente propensas a desenvolver mau alinhamento axial. Fato que não foi observado por Johnson et al. ${ }^{(14)}$. Neste trabalho, resultaram 4 fraturas com e 4 fraturas com varos menores iguais a $15^{\circ}$ como também 10 torções femorais abaixo iguais a $10^{\circ}$. Apesar do cuidado com a redução da fratura, mesmo assim, houve uma média de encurtamento de 1,23 cm (minímo de 0,5 e máximo $4 \mathrm{~cm}$ ). Os casos que apresentaram encurtamento e desvio rotacional eram, respectivamente, cominutivas e fraturas em espiral, segundo Winquist \& Hansen ${ }^{(32)}$ apesar de ser a haste bloqueante a melhor indicação para essas fraturas.

O encurtamento do fêmur foi encontrado em 81 casos, na variação de 0,5 a $4 \mathrm{~cm}$. O caso de encurtamento igual a $4 \mathrm{~cm}$ também é relatado por Thörensen et al. ${ }^{(30)}$ que tiveram resultados entre 2,1 a $9 \mathrm{~cm}$ enquanto que Wiss et al. ${ }^{(34)}$ obtiveram entre $1 \mathrm{e}$ $2 \mathrm{~cm}$. Nesse trabalho somente uma fratura evoluiu para $4 \mathrm{~cm}$ de encurtamento. Além disto, foi encontrado encurtamento do fêmur em 80 fraturas, com variação de $0,5 \mathrm{~cm}$ a $3 \mathrm{~cm}$. O paciente citado com encurtamento de $4 \mathrm{~cm}$ evoluiu com quase $2 \mathrm{~cm}$ de encurtamento além do observado no pós-operatório imediato.

Outra complicação resultante foi a ocorrência de varismo em 4 casos durante o período pós-operatório; graus de 10, 8, 4 e 15 respectivamente como também fraturas tipo espiral, cominutiva, distal, cominutiva e proximal também respectivamente ao número de ordem citado acima. As causas que podem ter levado a estas complicações se atribui a parafusos fora do furo, quebra ou vergamento dos parafusos ou haste. As fraturas consolidaram e não houve implicação clínica e estética no resultado obtido.

Quanto à possibilidade, relatada no tratamento das fraturas femorais instáveis, de refratura após retirada do material de síntese e que ocorre no tratamento com placas e parafusos ${ }^{(35)}$, essa complicação foi observada em um caso das 18 retiradas de materia. Essa complicação foi observada em um caso ao retirar a haste, com 13 meses, consolidada com história de infecção tratada com irrigação contínua e na ocasião de sua hospitalização foi realizada desbridamento seguido de limpeza cirúrgica e irrigação contínua e com 3 dias após este tratamento foi indicado a haste bloqueada. Com evolução clínica de 12 meses, observou-se a presença de infecção, indicando-se a retirada da haste uma vez que a fratura já estava consolidada. Para dar continuidade ao tratamento da infecão optou-se pela fixação externa e três dias após este procedimento houve refratura a qual foi mantida com fixador externo.

Com relação à quebra dos implantes, houve 6 casos nos parafusos distais e todos ocorreram no mais proximal ao foco de fratura. Bucholz \& Jones ${ }^{(8)}$ admitiram em seu trabalho ser o estresse, no furo mais cranial da parte distal, marcadamente aumentado nas fraturas distais de diáfise femural, e que fraturas por fadiga de haste intramedular são possíveis quando este parafuso é inserido a menos de $5 \mathrm{~cm}$ do foco de fratura. Todavia, a quebra da haste intramedular de Küntscher não é um problema clínico sério, mas Zimmerman \& Klasen ${ }^{(36)}$ relataram que pode ser um risco maior com o sistema de bloqueio de haste. Assim pode-se achar como uma causa provável da quebra desses parafusos deste trabalho shortening besides the one observed in the immediate post-operatory.

Another resulting complication was the occurrence of varism in 4 cases during the post-operatory period grades 10, 8, 4 and 15, respectively spiral, comminutive, distal, and comminutive and proximal fractures. The causes of this complication are attributed to screws out of the hole, rupture or bending the screw or nail. The fractures consolidated and there were no clinical and esthetic implications in the result.

Concerning the possibility of re-fractures, reported in the treatment of the unstable femoral fractures, after withdrawal of the synthesis material and which occur in the treatment with plates and screws ${ }^{(35)}$, this complication was observed in 1 case among 18. This complication was observed in one case when the nail was withdrawn, after 13 months, consolidated with history of infection treated with continuous irrigation and, at admission to hospital, débridement was carried out followed by surgical cleaning and continuous irrigation; 3 days after, locking nailing was indicated. After a clinical evolution of 12 months, infection was detected and nail withdrawal was indicated since the fracture was already consolidated. In order that the infection treatment continued we chose external fixation and three days after this procedure re-fracture occurred and was sustained with external fixator.

Concerning rupture of the implants, there were 6 cases in distal screws and all occurred most proximal to the fracture focus. Bucholz \& Jones ${ }^{(8)}$ admitted that stress in the most cranial hole of the distal part is markedly increased in the femoral diaphysis distal fractures, and that fractures due to intramedullary nail fatigue may happen when this screw is inserted less than $5 \mathrm{~cm}$ far from the fracture focus. However, rupture of Küntscher intramedullary nail does not represent a serious clinical problem, but Zimmerman \& Klasen ${ }^{(36)}$ reported that it can be a greater risk with the nail locking system. Thus, it can be cosnsidered the probable cause of rupture of the screws in this study as reported by Bucholz \& Jones ${ }^{(8)}$ and the second cause is that the fracture was distal and, thus, the screws were at a distance shorter than $5 \mathrm{~cm}$

Also concerning rupture of the implant material, one could observe that the greater number of rupture and bending of nails and screws occurred in those cases in which $1.22 \mathrm{~mm}$ wall thickness FMRP nail was used and also $4.5 \mathrm{~mm}$ screws totalling $7.77 \%$. We can deduce that the $2.0 \mathrm{~mm}$ nails and the $16 \mathrm{~mm}$ distal screws are more resistant materials and that kind of complication is less observed, $6.8 \%$.

One must emphasize that the higher index of complication due to nails and screws rupture and bending was $14.56 \%$ of the operated on cases with the FMRP locking nail. The higher number has occurred with the $1.2 \mathrm{~mm}$ thick nail (7.77\%). This is also due to adjustment in the implant material and instruments resistance. It was also observed using the $2.9 \mathrm{~mm}$ thick nail, $6.8 \%$. This variation may have occurred because it has been applied during the phases of ajustment of resistance, in spite that mechanical tests had been carried out evidencing more resistance of the materia/(22) .

During the study it was evidenced that ruptures and bendings can also have occurred due to proximity of the more distal cranial hole 
conforme relato de Bucholz \& Jones ${ }^{(8)}$ e como segunda causa foi porque a fratura era distal e portanto os parafusos ficaram numa distância inferior a $5 \mathrm{~cm}$.

Ainda com relação às quebras do material de implante, pôde-se observar que o maior número de quebra e vergamento das hastes e parafusos ocorreu naqueles casos em que foram utilizados a haste FMRP de 1,2 mm de espessura de parede como também os parafusos de 4,5 mm de rosca total em torno de 7,77\%. Desta forma, pode-se deduzir que a haste de $2,0 \mathrm{~mm}$ e parafusos de rosca de $16 \mathrm{~mm}$ distais são materiais mais resistentes e, por isso, ocorre, em menor número, 6,8\% aquele tipo de complicação.

Ressalta-se que o maior índice das complicações de quebras e vergamentos das hastes e parafusos foi de $14,56 \%$ dos casos operados com a haste bloqueada FMRP. Registrando-se maior ocorrência na haste de 1,2mm de espessura (7,77\%). Isto deve-se ao fato dos ajustes na resistência do material de implante e instrumental. Também aconteceu na haste de 2,0 mm de espessura, porém em menor percentual 6,8\%. Acredita-se que esta intercorrência nesta haste tenha ocorrido talvez por ter sido aplicada haste ainda em fase de ajuste na resistência, apesar de ter sido realizado testes mecânicos, comprovando maior resistência do material (22).

Pelos estudos, ficou comprovado que as quebras e vergamentos podem ter sido também em virtude da proximidade do furo distal mais cranial próximo ao foco de fratura ${ }^{(6,7,9,11)}$. Ressaltase que o furo distal mais cranial deve ser preenchido com parafusos, a uma distância de $5 \mathrm{~cm}$ do foco ao $1^{\circ}$ furo da haste mais distal cranial a fim de não diminuir a resistência da haste conforme Fischer \& Hamblen ${ }^{(11)}$.

Finalmente, pontua-se que a quebra dos materiais de implante pode ocorrer devido à dificuldade que se tem na avaliação precisa do processo de consolidação dessas fraturas, por exemplo: a exuberante formação de calo ósseo que nem sempre representa suficiente resistência mecânica para o suporte da carga, favorecendo assim a solicitação excessiva do implante, que tiveram quebra e vergamento da haste e parafusos, como consequência de falha na avaliação radiográfica que deveria ter sido mais apurada a fim de evitar tal intercorrência.

A utilização da fixação intramedular bloqueada no tratamento das fraturas diafisárias cominutivas do fêmur é vantajosa, quando comparada aos outros materiais semelhantes de osteossíntese, porque:

- não necessita de material especializado a não ser o material de implante e instrumental especial desenvolvido no Hospital das Clínicas da Faculdade de Medicina de Ribeirão Preto;

- não necessita de mesa ortopédica, uma grande vantagem ao se lidar com pacientes politraumatizados;

- baixo índice de complicações;

- funcionalmente, excelente e bons resultados foram obtidos em $97,09 \%$ dos casos relatados;

- enfatiza a importância da abordagem das fraturas através de um miniacesso e a preocupação, cada vez maior, com o uso de intensificador de imagens nas salas cirúrgicas. with the fracture focus ${ }^{(6,7,9,11)}$. It is outlined that the more distal cranial hole must be filled with screws, at a $5 \mathrm{~cm}$ distance between the focus and the first hole of the most distal cranial nail, in order that the nail resistance is not reduced, according to Fischer \& Hamblen ${ }^{(11)}$.

Finally, rupture of the implant material can occur due to the difficulty to accurately evaluate the consolidation process of these fractures, for instance: the exhuberant formation of bone callus that not always represents sufficient mechanical resistance for load support, favoring the excessive solicitation of the implant which had rupture and bending of the nail and screws as a consequence of failure in the radiographic evaluation which should have been more accurate in order to avoid that incident.

The utilization of the intramedullary locking fixation in the treatment of the comminutive diaphyseal fractures is advantageous when compared with other similar materials for osteosynthesis, because:

- $\quad$ Specialized material is not necessary other than the implant and instrumental material developed in the "Hospital das Clínicas", Ribeirão Preto College of Medicine.

- $\quad$ Orthopedic tables are not necessary, a great advantage when the patients are polytraumatized.

- Low index of complication.

- Functionally, excellent and good results were obtained in 97.09\% of the reported cases.

- It emphasizes the importance of approaching the fractures through a miniaccess and the increasing preoccupation concerning the use of the image intensifier in operating rooms.

It was evidenced, also, that the FMRP locking nail can be used in complex diaphyseal fractures of the femur, possibilitating short stay in hospital, early march and lower costs. Since the intramedullary nail is the best option for the treatment of femoral fractures, from the anatomical, functional and physiological point of view, we conclude that the method attended to the clinical and biomechanical exigencies of femoral fractures, mainly comminutive, in which it was used. It is a feasible system and it is employed in Brazil. 
Constatou-se, ainda, que a haste bloqueada FMRP pode ser utilizada em fraturas diafisárias complexas do fêmur, possibilitando a brevidade de tempo de hospitalização, marcha precoce e custo menos oneroso. Por ser a haste intramedular a melhor opção para tratamento das fraturas do fêmur, do ponto de vista anatômico, funcional e fisiológico, conclui-se que esse método atendeu às exigências clínicas e biomecânicas das fraturas do fêmur principalmente as cominuídas nas quais foi utilizado. É um sistema viável e empregado no Brasil.

\section{REFERÊNCIAS}

1. Acker, J. H.; Murphy, C.; D' Ambrósio, R. Treatment of fractures of the femur with the Grosse-Kempf rod. Orthopedics, v. 8, p:1393-7, 1985.

2. Alho, A.; Stönsen, M. S. K.; Ekeland, A. Locked intramedullary nailing of femoral shaft fractures. J. Trauma, v. 31, p: 49-59,1991.

3. Böhler, J. Closed intramedullary nailing of the femur. Clin. Orthop., v. 60, p: 51-67, 1968.

4. Brumback, R. J.; Reily, J. P.; Poka, A.; Lakatos, R. P.; Bathon, G. H.; Burgess, A. R. Intramedullary nailing of femoral shaft fractures. Parte 1 Decisions-making errors with interlocking fixation. J. Bone Surg., v. 70-A, p: 336-40, 1988a.

5. Brumback, R. J.; Uwagie-Ero, S.; Lakatos, R. P.; Poka, A.; Bathon, G. $H$.; Burgess, A. R. Intramedullary nailing of femoral shaft fractures (Parte II). J. Bone Surg., v. 70-A, p: 336-40, 1988b.

6. Brumback, R. J.; Ellison Jr. P. S.; Poko, A.; Lakatos, R.; Bathon, G. H.; Burgess, A. R. Intramedullary nailing of open fractures of the femoral shaft. J. Bone Joint Surg. , v. 71-A, p: 1324-31, 1989.

7. Bucholz, R. W.; Rosse, S. E.; Laurence, K. Fatgue fracture of the interloking nail in the treatment of fractures of the part of the femoral shaft. J. Bone Joint Surg., v. 69-A, p: 1391-9, 1987.

8. Bucholz, R. W.; Jones, A. Current concepts review. Fractures of the shaft of the femur. J. Bone Joint Surg., (Am), v. 73, p: 1561-1566, 1991.

9. Cameron, C. D.; Meek, R. N.; Blachut, P. A. Intramedullary nailing of femoral shaft: a prospective randomized study. J. Orthop. Trauma, v. 6, p: 448-51, 1992.

10. Fernandes, H. J. A. Tratamento de fraturas diafisárias instáveis do fêmur com haste intramedular bloqueada, São Paulo, 1996. 59 p. Dissertação (mestrado)- Universidade Federal de São Paulo- Escola Paulista de Medicina.

11. Fischer, W. D.; Hamblen, D. L. Problems and pitfals of compression fixation of long bone fractures. A review of results and complication. Injury, v. 10, p: 99-107, 1978.

12. Grover, J.; Wiss, D. A. A prospective study of fractures of the femoral shaft treated with a statc, intramedullary, interlocking nail comparing one versus two distal screws. Orthop. Clinc. of North Am., v. 26, p: 139-46, 1995.

13. Gustilo, R. B.; Gruninger, R. P.; Davis, T. Classification of type III (severe) open fractures relative to treatment and results. Orthopedics, v. 10, p: 1781-8, 1987.

14. Johnson, K. D.; Johnston, D. W. C.; Parker, B. Comminuted femoralshft fractures:treatment by roller traction, cerclage wires and an intramedullary nail, or an interlocking intramedullary nail. J. Bone Joint Surg., v. 66-A, p: 1222-35, 1984.

15. Kempf, I.; Grosse, A.; Beck, G. Closed locked intramdullary nailing. J. Bone Joint Surg., v. 5, p: 709-20, 1985.

16. Klemm, K. W.; Börner, M. Interlocking nailing of complex fractures of the femur and tibia. Clin. Orthop., v. 212, p: 89-100, 1986.

17. Klemm, K. W.; Börner, M. Interlocking nailing of complex fractures of the femur and tibia. Clin. Orthop., v. 212, p: 89-100, 1989.
18. Kovacs, A. J.; Richard, L. B.; Miller, J. Infection complicating intramedullary nailing of the fractured femur. Clin. Orthop., v. 96, p: 266-70, 1973

19. Kwong, L. M.; Johanson, P. H.; Zinar, D. M.; Lenihan, M. R.; Herman, K. W. Shielding of the patients gonads during intramedullary interlocking femoral nailing. J. Bone Joint Surg., v. 72-A, p: 15236, 1990.

20. Mattos, C. A.; Zuppi, G. N.; Köberle, G.; Belangero, W. D. Tratamento das fraturas do fêmur pelo método de fixação biológica: placa em ponte e haste intramedular bloqueada. Rev. Bras. Ortop., v. 32, p: 425-30, 1997

21. Morelli, R. S. S.; Castro, A. C. B.; Assis, M. C.; Fernandes, M. S. Considerações sobre o tratamento das fraturas de fêmur com haste intramedular de Küntscher. Rev. Bras. Ortop., v. 28, p: 499-503, 1993.

22. Moro, C. A.; Paccola, C. A. J.; Paulin, J. B. P.; Paschoal, F. M.; Shimano, A. C. Um modelo para avaliar o comportamento mecânico de hastes intramedulares de fêmur. Rev. Bras. Engenharia, v.7, p: $572-801990$

23. Müller, M. E. The comprehensive classification of fractures of long bones. In: MÜLLER, M. E.; ALLGÖWER, M.; SCHNEIDER, R.; WILLEIEGGER, H. Manual of internal fixation: techniques recommend by the AO - ASIF Group. 3. ed. Berlim, Springer-Verlag, 1991, 118-50

24. Paccola, C. A. J.; Krettek, C.; Schandelmeier, P.; Mannss, J. Comparação das propriedades mecânicas das hastes femorais bloqueadas AO-ASIF e FMRP (1 ${ }^{\text {a }}$ parte). Rev. Bras. Ortop., v. 30, p: 765-71, 1995a.

25. Paccola, C. A. J.; Krettek, C.; Schandelmeier, P.; Mannss, J. Comparação das propriedades mecânicas das hastes femorais bloqueadas AO-ASIF e FMRP (2aparte). Rev. Bras. Ortop., v. 30, p: 869-77, 1995b.

26. Paccola, C. A. J.; Paschoal, F. M. An interlocking nail system for underdeveloped countries. AO/ASIF-Dialogue, p:11-15, 1991.

27. Paschoal, F. M. Haste bloqueante anti-telescopável Ribeirão Preto, Ribeirão Preto, 1990. 96 p. Dissertação (mestrado) - Faculdade de Medicina de Ribeirão Preto/Escola de Engenharia de São Carlos, Universidade de São Paulo.

28. Rodrigues, A. C. M.; Ortiz, J. Osteossintese intramedular no fêmur a foco fechado sem intensificador. Rev. Bras. Ortop., v. 23, p: 27982, 1988.

29. Skjeldal, S.; Backers, S. Interlocking nails radation dose in distal targeting. Arch. Orthop.. Traumatol. Surg., v.106, p: 179-81, 1987.

30. Thöresen, B. O.; Alho, A.; Ekeland, A.; Stromsoe, K.; Folleras, G.; Hankebo, A. Interlocking intramedullary nailing in femoral shaft fractures. A report of forty-eight cases. J. Bone Joint Surg., v. 67A, p: 1313- 20, 1985.

31. Weller, S.; Hönstsch, D. Medullary nailing of femur and tibia. In: Müller, M. E.; Allgöwer, M.; Schneider, R: Manual of internal fixation: $3^{\circ}$ ed., New York, Springer- Verlag, 1991, p: 292-304.

32. Winquist, R. A.; Hansen, Jr., S. T. Comminuted fractures of the femoral shaft treated by intramedullary nailing. Orthop. Clin. North Am., v. 2, n 3, p: 633-48, Jul, 1980.

33. Winquist, R. A.; Hansen, Jr., S. T.; Clawson, D. K. Closed intramedullary nailing of femoral fractures. J. Bone Joint Surg., V. 66-A, p: 529-39, 1984.

34. Wiss, D. A.; Fleming, C. H.; Matta, J. M.; Clark D. Comminuted and rotationally unstable fractures of the femur treated with an interlocking nail. Clin. Orthop., v. 212, p: 35-41, 1986.

35. Wu, C. C.; Shih, C. H. Effect of Dynamization of a Static Interlocking nail on fractures healing. Can. J. Surg., v. 36, $n^{\circ} 4$, p:302-306, 1993.

36. Zimmerman, K. W.; Klasen, H. J. Mechanical failure of intramedullary nails after fracture union. J. Bone Joint Surg., v. 65-B, p: 274-5, 1983. 